\title{
Projekt Logiki Infinitarnej Ernsta Zermela
}

\section{Ernst Zermelo's Project of Infinitary Logic}

\author{
Jerzy Pogonowski \\ Institute of Linguistics, Adam Mickiewicz University \\ ul. Międzychodzka 5, 60-371 Poznań, POLAND \\ pogoneamu.edu.pl
}

\begin{abstract}
This paper is a summary of a more comprehensive work Infinitarna Logika Ernsta Zermela (The Infinitary Logic of Ernst Zermelo) being currently under preparation for the research grant KBN 2H01A 00725 Metody nieskończonościowe $w$ teorii definicji (Infinitary methods in the theory of definitions) headed by Professor JANUSZ CZELAKOWSKI at the Institute of Mathematics and Information Science of the University of Opole, Poland. The presentation of Zermelo's ideas is accompanied with some remarks concerning the development of infinitary logic. ${ }^{1}$
\end{abstract}

\section{Uwagi wstępne}

Niniejszy tekst jest streszczeniem (obszerniejszej, niestety) rozprawy poświęconej omówieniu niezbyt chyba popularnego $\mathrm{w}$ środowisku logicznym projektu logiki infinitarnej (jako podstawy rozważań matematycznych) formułowanego przez Ernsta Zermelę mniej więcej siedemdziesiąt lat temu. Był to wówczas projekt prekursorski i nie spotkał się z większym zainteresowaniem luminarzy logiki, z różnych, nie tylko stricte logicznych, matematycznych i metodologicznych powodów. Jednak systematyczne, intensywne badania logik infinitarnych zostały, z wieloma spektakularnymi sukcesami, podjęte dwie dekady później.

Poszczególne punkty niniejszego streszczenia odpowiadają mniej więcej rozdziałom przygotowywanej rozprawy. Niektóre z nich (zwłaszcza fragment poświęcony roli paradoksu Skolema) są w rozprawie potraktowane o wiele obszerniej, niż może to wyglądać z perspektywy niniejszego tekstu. Staramy się w rozprawie przedstawić projekt Zermela na szerszym tle rozwoju badań metalogicznych w XX wieku, co w tym streszczeniu również odzwierciedlenia nie znajduje.

Ani to streszczenie, ani przygotowywana rozprawa nie rości sobie pretensji do jakiejś szczególnej oryginalności i kompletności, nie mówiąc już o odkrywczości. Korzystamy zarówno z tekstów samego Zermela (także tych pozostawionych w jego Nachlaß i publikowanych stopniowo przez kompetentnych logików badających jego twórczość), jak i dostępnych opracowań — monografii (klasycznych i nowszych) dotyczących historii logiki i podstaw matematyki oraz, oczywiście, rozproszonych w literaturze artykułów związanych z odnośną problematyką.

\footnotetext{
${ }^{1}$ Autor wyraża wdzięczność Panom Profesorom: Romanowi Murawskiemu, Janowi Woleńskiemu oraz Janowi Zygmuntowi za możliwość korzystania z ich kompetentnych opracowań dotyczących historii logiki, za pomoc w tropieniu źródeł bibliograficznych oraz za życzliwe rady i krytyczne komentarze udzielane w rozmowach i korespondencji. Osobne podziękowanie należne jest Panu Profesorowi Januszowi Czelakowskiemu za przyjazną ufność, iż piszący te słowa podoła intelektualnie wywiązać się z zaszczytnego dla niego zaproszenia do udziału we wspomnianym projekcie badawczym.
} 


\section{Zermelo: krótkie uwagi biograficzne}

Ernst Friedrich Ferdinand Zermelo (27 lipca 1871, Berlin — 21 maja 1953, Freiburg i. Br.) należy do najwybitniejszych matematyków pierwszej połowy XX wieku. Znany jest przede wszystkim jako twórca wersji aksjomatycznej teorii mnogości, rozwijającej idee Georga Cantora. Zajmował się także m.in.: rachunkiem wariacyjnym, zastosowaniami matematyki w fizyce, hydrodynamika, problemami nawigacji. Jedna z jego prac dotyczyła zastosowania teorii mnogości w grze w szachy. Odkrył antynomię Russella na kilka lat przed Russellem. Był tłumaczem dzieł matematycznych i literackich (fragmenty Odysei) oraz redaktorem naukowym Dziet zebranych Cantora.

Zermelo pracował na uniwersytetach w Getyndze, Zürichu oraz Freiburgu. Z jego nazwiskiem wiąże się pierwszy oficjalny kurs logiki matematycznej na uniwersytetach niemieckich. Podstawami matematyki zajmował się intensywnie w dwóch okresach: w Getyndze (1899-1910) pracując u boku Dawida Hilberta oraz we Freiburgu (1921-1935). To właśnie w tym drugim okresie powstawał jego projekt logiki infinitarnej.

Nie wydano dotąd dzieł zebranych Zermela. Interesujący projekt badawczy dotyczący spuścizny Zermela (z uwzględnieniem ważnych notatek pozostawionych w jego Nachlaß) prowadzono z udziałem m.in. Volkera Peckhausa oraz Heinza-Dietricha Ebbinghausa). Informacje (łącznie z bibliografią prac Zermela oraz licznymi artykułami omawiającymi jego twórczość) dostępne były na stronie internetowej hrz.upb.de/ apeck1/zermelo/id9.htm.

\section{Teoria mnogości Zermela}

Koniec XIX oraz początek XX wieku to okres, w którym intensywnie pracowano nad aksjomatycznymi charakterystykami podstawowych struktur matematycznych: liczbowych, algebraicznych, geometrycznych (Peano, Dedekind, Postulatyści Amerykańscy [Veblen, Huntington i in.], Hilbert). Nowa wówczas teoria mnogości Cantora także poddana została aksjomatyzacji. Zermelo przedstawił swoją aksjomatykę w 1908 roku (zob. [Zermelo 1908]); o jego aksjomatyce z 1930 roku (tj. o artykule [Zermelo 1930]) wspominamy w następnym punkcie. Jest rzeczą znaną, że aksjomatyka z 1908 roku, tworzona w duchu pierwszej fazy programu Hilberta, nie tylko miała ustrzec teorię mnogości przed antynomiami, ale przede wszystkim służyła Zermeli do uzasadnienia jego twierdzenia o możliwości dobrego uporządkowania każdego zbioru.

Inne aksjomatyki teorii mnogości (np. Fraenkel, Bernays, von Neumann, Gödel, Quine) i uzupełnienia bądź modyfikacje aksjomatów (np. Skolem, Mirimanoff) tworzone były już w obecności aksjomatyki Zermela z 1908 roku. Przez ok. pół wieku teoria mnogości uprawiana była jako teoria matematyczna, później rozpoczęły się jej badania prowadzone także z perspektywy teorii modeli.

Zakładamy, że ewentualny Czytelnik tego tekstu zna współczesną, będącą powszechnie używanym standardem aksjomatykę Zermelo-Fraenkla dla teorii mnogości w języku pierwszego rzędu, z aksjomatem wyboru, teorii oznaczanej dalej, zgodnie ze zwyczajem, przez ZFC. W niniejszym streszczeniu nie zamieszczamy informacji o początkach aksjomatyzacji teorii mnogości oraz o recepcji odnośnych prac Zermela z 1904 ([Zermelo 1904] — o możliwości dobrego uporządkowania dowolnego zbioru) i 1908 roku ([Zermelo 1908] — pierwsza aksjomatyka teorii mnogości, [Zermelo 1908a] — nowy dowód twierdzenia o możliwości dobrego uporządkowania dowolnego zbioru). ${ }^{2}$ Uczynimy jedynie dwie bardzo ogólnikowe (i niezbyt odkrywcze) uwagi:

- jak się wydaje, dwoma ważnymi czynnikami, które przyczyniły się w pierwszej mierze do wyodrębnienia predykatu $\in$ należenia elementu do zbioru poza logikę (w dziedzinę podstaw matematyki) były: 1) wspomniane wyżej aksjomatyzacje Zermela oraz 2) twierdzenie Löwenheima-Skolema ([Löwenheim 1915], [Skolem 1919, 1920, 1922]);

\footnotetext{
${ }^{2}$ Zob. np. [Fraenkel, Bar Hillel, Levy 1973], [Hallet 1984], [Kanamori 1996, 2004], [Moore 1980, 1982].
} 
- aksjomat wyboru zmieniał swój status: bywał traktowany czasem jako zasada logiczna, a czasem jako aksjomat charakteryzujący jedynie określonego rodzaju obiekty matematyczne, a mianowicie zbiory.

Nadto, czas w którym powstawał projekt logiki infinitarnej Zermela to okres tworzenia się podstawowych pojęć metalogicznych. Inkryminowane pomysły Zermela nie należały wówczas do głównego nurtu badań logicznych, prowadzącego do uznania logiki pierwszego rzędu za wzorcowy, podstawowy system logiczny. Omawiany okres to interregnum - między paradygmatem Principia Mathematica a paradygmatem Grundlagen der Mathematik oraz okrzepnięciem standardu logiki pierwszego rzędu (lata czterdzieste XX wieku) i powstaniem teorii modeli. ${ }^{3}$

Rola badań Zermela w obu fazach programu Hilberta była odmienna — w pierwszej fazie, gdy Zermelo był współpracownikiem Hilberta w Getyndze, powstała aksjomatyzacja z 1908 roku, całkowicie w duchu metodologii propagowanej przez Hilberta. W swoich pracach z lat dwudziestych i trzydziestych Zermelo nie akceptuje finistycznego punktu widzenia w podstawach matematyki. ${ }^{4}$

\section{Antyskolemizm Zermela}

Jak wiemy z zachowanej korespondencji ${ }^{5}$, Zermelo późno dowiedział się o wynikach uzyskanych przez Skolema, tj. o pracach [Skolem 1919, 1920, 1922]. W swoim słynnym artykule z 1930 roku w przypisie do sformułowania aksjomatu wyróżniania odnosi się (uszczypliwie, jak miał to w zwyczaju) do krytycznych uwag Skolema z 1930 roku (zob. [Skolem 1930]) o jego aksjomatyce teorii mnogości (konkretnie, o rozumieniu pojęcia Definitheit przedstawionym w [Zermelo 1929], ważnym dla postaci aksjomatu wyróżniania w sformułowaniu z 1908 roku). Przeciwstawienie się temu, co Zermelo nazywał skolemizmem oraz przesadami finitystycznymi było, jak się wydaje, główną inspiracja $\mathrm{w}$ jego projekcie logiki infinitarnej.

Nie jest celem tego streszczenia szczegółowa refleksja nad paradoksem Skolema. ${ }^{6}$ Istnieje na ten temat olbrzymia literatura, godne polecenia wydają się np. pozycje: [Benacerraf, Wright 1985], [Bays 2000], [van Dalen, Ebbinghaus 2000], [George 1985], [Klenk 1976], [McCarthy, Tennant 1987], [Moore 1985], [Myhill 1951, 1952], [Putnam 1980], [Quine 1966], [Resnik 1966, 1969], [Shapiro (Ed.) 1996], [Suszko 1951], [Thomas 1968, 1971], [Wang 1955]. Klarowne uwagi znaleźć można również w wielu podręcznikach, np.: [DeLong 1970], [Mostowski 1948], [Hunter 1971] (tłumaczenie polskie: [Hunter 1982]), [Wang 1962].

Jak wiadomo, twierdzenie Löwenheima-Skolema stwierdza (w dzisiejszej terminologii), że dowolna teoria w języku pierwszego rzędu, która ma model, ma też model przeliczalny. Jest to więc twierdzenie metalogiczne, zaliczane do tzw. twierdzeń limitacyjnych (mówiących coś o ograniczeniach logiki, metody aksjomatycznej, itd.). Wskazuje się na dwa (rzekomo) paradoksalne aspekty tego twierdzenia:

- W językach pierwszego rzędu, w których dysponujemy tylko przeliczalną liczbą termów domkniętych, nie możemy nazywać wszystkich elementów w uniwersach, których moc jest nieprzeliczalna.

- W teorii mnogości ZFC, zapisanej w języku pierwszego rzędu, twierdzenie Löwenheima-Skolema, łącznie z twierdzeniem Cantora (o nierównoliczności danego zbioru z rodziną wszyst-

\footnotetext{
${ }^{3}$ Osobny fragment przygotowywanej rozprawy to próba prześledzenia procesu tworzenia (się?) wybranych pojęć metalogicznych — pełności, (różnych odmian) kategoryczności, zupełności, zwartości, itp.

${ }^{4} \mathrm{~W}$ przygotowywanej rozprawie wspominamy, na miarę swoich sił, o pewnych późniejszych ustaleniach w teorii mnogości, np. o przejściu od relatywizmu Skolemowskiego do relatywizmu Cohenowskiego, o roli twierdzeń limitacyjnych w metateorii teorii mnogości, itd.

${ }^{5}$ Zob. [Ebbinghaus 2001].

${ }^{6} \mathrm{~W}$ rozprawie, której streszczeniem jest niniejszy tekst omawiamy w miarę obszernie problematykę dotyczącą paradoksu Skolema.
} 
kich jego podzbiorów) zdaje się prowadzić do wniosków paradoksalnych, rzekomo przeczących naszym intuicjom. Skoro w ZFC mamy aksjomat nieskończoności i zachodzi twierdzenie Cantora, to w ZFC daje się udowodnić istnienie zbiorów nieprzeliczalnych. Ale z twierdzenia Löwenheima-Skolema, jeśli ZFC ma jakikolwiek model, to ma też model przeliczalny. Jak w modelu przeliczalnym „zmieścić” się mogą zbiory, o których można udowodnić, iż są nieprzeliczalne? Nadto, wiele pojęć teoriomnogościowych (np. przeliczalność, moce nieskończone) zdaje się mieć charakter relatywny; mówi się czasem o tzw. relatywizmie wczesnoskolemowskim).

Eksplikacje paradoksu Skolema (zwłaszcza drugiego z wymienionych wyżej jego aspektów) są znane od dawna. Dla przykładu, przytoczmy dwa cytaty: z podręcznika Mostowskiego z 1948 roku oraz polskiego tłumaczenia podręcznika Huntera z 1971 roku.

Upatrując sprzeczność w istnieniu modelu przeliczalnego dla aksjomatów teorii mnogości, popełniliśmy więc ten sam błąd, jaki prowadzi do antynomii semantycznych (por. Rozdział XII, 3, str. 315): nie odróżniliśmy pojęć systemu teorii mnogości od pojęć meta-matematycznych.

Model teorii mnogości określony jest $\mathrm{w}$ meta-matematyce $\mathrm{w}$ zbiorze przeliczalnym; w modelu tym spełnione jest twierdzenie: istnieją mnogości nieprzeliczalne. Słowo przeliczalny ma za każdym razem inny sens: w pierwszym przypadku jako pojęcie z meta-matematyki, a w drugim — jako pojęcie z aksjomatycznego systemu teorii mnogości.

[Mostowski 1948: 359-360]

Paradoks Skolema nie jest sprzecznością, a na tle naszych dotychczasowych rozważań nie jest nawet rzeczywistym paradoksem. Niech $K$ będzie teorią pierwszego rzędu stanowiącą aksjomatyzację teorii zbiorów, $U$ zaś niech będzie twierdzeniem w $K$, które przy swej zamierzonej interpretacji znaczy tyle, co „Istnieje nieprzeliczalnie wiele zbiorów”. Wówczas jeżeli $K$ ma model, to istnieje taki model $K$, w którym $U$ nie głosi, że istnieje nieprzeliczalnie wiele zbiorów, ani nawet że istnieje nieprzeliczalnie wiele przedmiotów jakiegokolwiek rodzaju. Nasze dowody odpowiednich metatwierdzeń pokazują, że jeśli $K$ posiada model, to w ramach pewnego normalnego modelu $K$ twierdzenie $U$ w ogóle nie dotyczy zbiorów, lecz termów domknietych w $K$. Ponieważ w modelu tym $U$ jest prawdziwe, a istnieje tylko przeliczalnie wiele termów domkniętych w $K$, wiec $U$ nie znaczy w tym modelu tyle, co „Istnieje nieprzeliczalnie wiele termów domkniętych". Wyraża ono jaką́s prawdę o termach domkniętych w $K$. Jeśli zaś istnieje model $K$, którego dziedzina jest przeliczalna, a w którym $U$ głosi coś o zbiorach, to również w tym modelu $U$ nie znaczy tyle, co „Istnieje nieprzeliczalnie wiele zbiorów takiego a takiego rodzaju”; ma tam ono inny sens.

[Hunter 1982: 170]

Zwykle dodaje się także, że to, iż można udowodnić, że w danym modelu przeliczalnym dla ZFC istnieją zbiory nieprzeliczalne oznacza po prostu, że w modelu tym jest ,zbyt mało" zbiorów — w szczególności nie istnieją w nim funkcje ustalające np. równoliczność zbioru wszystkich liczb naturalnych w tym modelu z rodziną wszystkich jego podzbiorów w tym modelu, a stąd (na mocy definicji nieprzeliczalności) ta ostatnia rodzina jest (w tym modelu) zbiorem nieprzeliczalnym.

O twierdzeniu Löwenheima-Skolema dla systemów logiki różnych od klasycznej logiki pierwszego rzędu obszerne informacje znaleźć można np. w monografiach: [Barwise, Feferman (Eds.) 1985], [Shapiro (Ed.) 1996].

Antyskolemizm Zermela przejawia się w dwóch aspektach:

- niezgody na ograniczenia nakładane na własności, o których mowa w aksjomacie wyróżniania do własności wyrażanych formułami języka pierwszego rzędu (problem definite property); 
- niezgody na traktowanie teorii mnogości jako mogącej dotyczyć jakiegoś jednego, np. (zgroza!) przeliczalnego modelu.

Problemem poprawnego określenia pojęcia definite property zajmowało się wiele znakomitości ówczesnych (Zermelo, Fraenkel, Weyl, Skolem, von Neumann, i in.). Poniżej ograniczymy się do krótkiego przedstawienia propozycji Zermela.

\subsection{Zermelo o pojęciu Definitheit}

W opublikowanym w 1929 roku w Fundamenta Mathematicae artykule „Über den Begriff der Definitheit in der Axiomatik" (datowanym w Bad Zoppot, 11 lipca 1929, zob. [Zermelo 1929]) Zermelo podejmuje próbę sprecyzowania pojęcia Definitheit na drodze aksjomatycznej. Pojęcie to, jak wiadomo, odgrywa podstawową rolę w sformułowaniu aksjomatu wyróżniania. Zermelo nawiązuje do swojej prezentacji aksjomatyki teorii mnogości z 1908 roku. Rozważa trzy możliwości uporania się z trudnościami, jakie wiążą się z tym pojęciem:

1. potraktowanie go jako zbędnego (to rozwiązanie odrzuca; ważne jest przy tym, że Zermelo nie uważa, iż charakterystyka tego pojęcia miałaby zostać przeprowadzona w samej logice, poza teorią mnogości);

2. uniknięcie ogólnej charakterystyki tego pojęcia, poprzez jego specjalizacje - wyraźne podanie, jaką postać mogą mieć formuły zdaniowe wykorzystywane w aksjomacie wyróżniania; jako przykład takiego rozwiązania podaje propozycję Fraenkla z drugiego wydania (1923) jego Einleitung in die Mengenlehre; również to rozwiązanie Zermelo odrzuca - m.in. dlatego, że w rozwiązaniu Fraenkla korzysta się z pojęcia liczby naturalnej, a dla Zermela pojęcie to jest wtórne względem pojęć czysto teoriomnogościowych;

3. aksjomatyczna charakterystyka rozważanego pojęcia — i to jest właśnie rozwiązanie, które Zermelo proponuje w dalszej części pracy; zwraca przy tym uwagę na inną próbę tego rodzaju, a mianowicie propozycję von Neumanna z 1925 roku aksjomatyzacji teorii mnogości, z pojęciem funkcji jako pierwotnym.

Należy zwrócić uwagę, że Zermelo nie komentuje propozycji Thoralfa Skolema przedstawionych kilka lat wcześniej. Jak wynika z korespondencji pozostawionej w Nachlaß, Zermelo nie znał pracy Skolema - po raz pierwszy cytuje Skolema dopiero w przypisie w swoim artykule z 1930 roku. Sam Skolem, krytykując rozwiązanie Zermela, które za chwilę omówimy, pisze:

Dabei fällt es mir besonders auf, daß er meinen Helsingforser Vortrag vom Jahre 1922 nicht zu kennen scheint, worin ich genau dieselbe Idee zur Verschärfung jenes Begriffes ausgesprochen habe wie Zermelo auf Seite 342 in seiner Arbeit.

[Skolem 1930: 275]

Po wyjaśnieniach dotyczących rozumienia potrzebnych pojęć wstępnych (system aksjomatyczny, model, niesprzeczność, kategoryczność, itp.) Zermelo twierdzi, że jego dotychczasowe rozumienie pojęcia Definitheit można ują́ następująco: ${ }^{7}$

„Definit” ist also, was in jedem einzelnen Modell entschieden ist, aber in verschiedenen Modellen auch in verschiedener Weise entschieden sein kann;

[Zermelo 1929: 341].

\footnotetext{
${ }^{7}$ Wszystkie cytaty $\mathrm{z}$ prac Zermela wykorzystywane $\mathrm{w}$ tym streszczeniu podaję $\mathrm{w}$ oryginale niemieckim (z jednym wyjątkiem — zob. 3.3. niżej). Rozważam podanie ich w tłumaczeniu polskim w przygotowywanej rozprawie.
} 
Tak więc, własnością określoną miałaby być każda własność, dla której w dowolnym modelu rozważanego systemu aksjomatów możemy orzec, czy przysługuje ona elementom uniwersum tego modelu. Nieprecyzyjność tego określenia jest — dzisiaj — widoczna. Zermelo nie nakreśla ostro granic języka, w którym formułowane mogą być owe własności określone. Są nadto owe własności wyznaczane treściowo, a nie - jak to czynimy dzisiaj, idąc za propozycją Skolema — czysto formalnie (syntaktycznie). Jako przykład własności, które nie są w powyżej cytowanym sensie określone podaje Zermelo np. być zbiorem pomalowanym na zielono lub być liczbq niewymierna, która nie może zostać zdefiniowana w skończonej liczbie słów żadnego jezyka europejskiego. Stwierdza — z oczywistym sarkazmem - że nie należy traktować takich własności jako bezsensownych, skoro za pomoca podobnych środków próbowano wykazywać, że kontinuum nie może zostać dobrze uporządkowane.

$\mathrm{Z}$ powyższego powinno być widoczne, że dotąd Zermelo rozumiał własności określone (dla danego systemu aksjomatycznego) jako te własności, które są dla rozważanego systemu istotne, dorzeczne, naturalne, itp.; powstaje więc np. pytanie, czy takie rozumienie własności określonej jest nie tylko uwarunkowane treściowo, ale również pragmatycznie.

W dalszej części pracy Zermelo uznaje za nieadekwatne następujące ogólne określenie własności określonej (zdania wyrażającego własność określoną):

Ein Satz heißt „definit” für ein gegebenes System, wenn er aus den Grundrelationen des Systems aufgebaut ist ausschließlich vermöge der logischen Elementar-Operationen der Negation, Konjunktion und Disjunktion sowie der Quantifikation, alle diese Operationen in beliebiger aber endlicher Wiederholung und Zusammensetzung.

[Zermelo 1929: 342].

Powodem odrzucenia jest tu fakt, że definicja tego kształtu (definicja genetyczna) odwołuje się nie do samego zdania (wyrażającego własność określona), lecz do sposobu jego konstrukcji, a ten ostatni wymaga uwzględnienia pojęcia dowolnej skończonej liczby (naturalnej), co jest dla Zermela niedopuszczalne.

Wreszcie, Zermelo podaje — jego zdaniem jedynie trafną — aksjomatyczną charakterystykę pojęcia własności określonej. Dla danej dziedziny $B$ oraz określonych na niej relacji podstawowych, tworzących system $R$ podane są trzy aksjomaty, charakteryzujące pojęcie „zdanie $p$ jest określone ze względu na $R$ " (symbolicznie: $D p$ ). Po pierwsze, zdaniami określonymi są wszelkie wyrażenia postaci $r(x, y, z, \ldots)$, dla dowolnej relacji z $R$ oraz dowolnej kombinacji zmiennych z $B$ (dla tego typu wyrażeń używa Zermelo terminu Grundrelationen). Po drugie, zdania utworzone ze zdań określonych poprzez użycie negacji, koniunkcji, alternatywy oraz kwantyfikacji (po zmiennych przebiegających dziedzinę $B$ ) również są określone. Nadto, Zermelo dopuszcza także kwantyfikację drugiego rzędu:

Gilt $D F(f)$ für alle definiten Funktoren $f=f(x, y, z, \ldots)$, so gelten auch $D \bigcap_{f} F(f)$ und $D \bigcup_{f} F(f)$.

[Zermelo 1929: 343].

(to ten właśnie warunek krytykowany jest w nocie [Skolem 1930]).

Nadto Zermelo zauważa, iż dwa pierwsze aksjomaty mówią jedynie, jakie zdania są określone, nie dostarczają natomiast informacji, jakie zdania określone nie sa. Zadanie to ma spełnić aksjomat III, będący swego rodzaju zasadą domknięcia:

Axiom III) Ist $P$ das System aller, ,definiten” Sätze, oder allgemeiner irgend ein System von Sätzen $p$ von der Beschaffenheit $D p$, so besitzt es kein echtes Untersystem $P_{1}$, welches gemäß I und II einerseits die sämtlichen Grundrelationen aus $R$ enthält, anderseits aber alle Negationen, Konjunktionen, Disjunktionen und Quantifikationen der eigenen Sätze, bzw. Satzfunktionen bereits umfaßt. 
Zermelo jest świadom, że powyższe sformułowanie niejawnie odwołuje się do stosowania skończonq liczbe razy operacji syntaktycznych, twierdzi jednak, iż potrafi się pozbyć tego odwołania, obiecując przedstawić szczegóły w późniejszej pracy (prawdopodobnie jest nią [Zermelo 1935], ostatni tekst ogłoszony przez niego drukiem).

\subsection{Zermela wizja świata teorii mnogości z 1930 roku}

Artykuł Über Grenzzahlen und Mengenbereiche. Neue Untersuchungen über die Grundlagen der Mengenlehre. Fundamenta Mathematicae 16, 1930, $29-47$ (zob. [Zermelo 1930]), niezwykle ważny w dorobku Zermela rozpatrywać można m.in. w dwóch aspektach:

- jako świadectwo pewnego etapu w rozwoju poglądów Zermela na teorię mnogości; sądzimy, że można mówić o trzech takich etapach:

- 1. prace z 1904 oraz 1908 roku;

- 2. artykuł z 1930 roku;

- 3. notatki pozostawione w Nachlaß;

- jako pewien punkt wyróżniony w ewolucji poglądów Zermela na podstawy logiki i matematyki (do tego momentu Zermelo - przynajmniej w druku — wydaje się akceptować finitarny charakter konstrukcji składniowych; po artykule [Zermelo 1930] rozpocznie szkicowanie swojego programu logiki infinitarnej, w jego zamierzeniu adekwatnej dla inferencji matematycznych).

Przedstawimy tu krótko pierwszy z tych aspektów.

Zermelo zna już (jak wiadomo na podstawie jego korespondencji z Baerem) pracę Skolema z 1922 roku, jest więc świadom wczesnoskolemowskiego relatywizmu teoriomnogościowego; uznaje konieczność dołączenia aksjomatu zastępowania; wykorzystuje reprezentację liczb porządkowym $\mathrm{w}$ stylu von Neumanna. Czyni istotny użytek z liczb nieosiągalnych, wyznaczających te piętra w pozaskończonej hierarchii dziedzin, które są (naturalnymi) modelami systemu aksjomatów teorii mnogości. Podaje twierdzenia charakteryzujące z dokładnością do izomorfizmu (uwzględniającego dwa parametry: liczbę atomów oraz charakterystykę porządkową dziedziny) swoje dziedziny normalne. Przedstawia świat teoriomnogościowy jako pozaskończoną hierarchię dziedzin normalnych. Odrzuca możliwość, aby świat ów reprezentować jednym modelem. Odkłada (szczęśliwie!) na później kwestie metateoretyczne, w rodzaju istnienia dowodu niesprzeczności badanego systemu aksjomatów.

Aksjomaty systemu z pracy [Zermelo 1930]:

$\begin{array}{lll}{[\mathrm{B}]} & \text { Bestimmtheit } & \text { Ekstensjonalności } \\ {[\mathrm{A}]} & \text { Aussonderung } & \text { Wyróżniania } \\ {[\mathrm{P}]} & \text { Paarung } & \text { Pary } \\ {[\mathrm{U}]} & \text { Potenzmenge } & \text { Zbioru potęgowego } \\ {[\mathrm{V}]} & \text { Vereinigung } & \text { Sumy } \\ {[\mathrm{E}]} & \text { Ersetzung } & \text { Zastępowania } \\ {[\mathrm{F}]} & \text { Fundierung } & \text { Ufundowania }\end{array}$

Są podobieństwa i różnice między tym systemem aksjomatów, a systemem z 1908 roku.

Zermelo rozważa teorię mnogości, w której oprócz zbiorów występują także obiekty „nierozkładalne", o nieznanej strukturze, tzw. Urelemente. Ich ogół to kolekcja $U$. Elementy $U$ nazywać będziemy także atomami. 
Aksjomat wyróżniania [A] sformułowany jest, chciałoby się rzec, pamiętając ustalenia Zermela $\mathrm{z}$ artykułu [Zermelo 1929], w języku drugiego rzędu (z dopuszczeniem kwantyfikacji po funkcjach zdaniowych). Sam Zermelo nie precyzuje języka, w którym wyrażalne są własności zbiorów. Pisze jedynie, że catkiem dowolna funkcja zdaniowa wyznaczać może podzbiór danego zbioru; nadto, każdej części (Teil) danego zbioru odpowiada zbiór, mający za swe elementy wszystkie elementy tej części.

Także na funkcje występujące w aksjomacie zastępowania nie nakłada się żadnych ograniczeń. Mamy więc tu do czynienia $\mathrm{z}$ aksjomatem, a nie ze schematem aksjomatów.

Dodany (do systemu z 1908 roku) jest aksjomat ufundowania. Zermelo pisze, że aksjomat ten wymagany jest dla wykluczenia ,zirkelhafte” und ,abgründige” Mengen.

Nie zakłada się aksjomatu nieskończoności, jako - wedle słów Autora - nie należącego do „allgemeinen” Mengenlehre, ogólnej teorii mnogości. Jak pokazuje się dalej, dziedzina normalna złożona z wszystkich zbiorów skończonych spełnia aksjomaty systemu.

W aksjomacie zbioru potęgowego postuluje się istnienie rodziny wszystkich podzbiorów dowolnego zbioru; dodaje się uwagę: An die Stelle der „Nullmenge” tritt hier ein beliebig ausgewähltes „Urelement” $u_{0}$.

Aksjomat wyboru, zakładany jako zasada logiczna, nie jest zaliczany do aksjomatów systemu. Zermelo pisze, że aksjomat ten nie może służyć do ograniczania (wielkości?) rozważanych dziedzin (Abgrenzung der Bereiche). Dodaje, iż we wszystkich dalszych badaniach podstawowy jest fakt, że każdy zbiór można dobrze uporządkować.

Systemy złożone ze zbiorów oraz atomów, z określoną relacją podstawową $a \in b$ (a jest elementem $b$ ) spełniające aksjomaty BAPUVEF nazywa Zermelo dziedzinami normalnymi (Normalbereiche). Na dziedzinach normalnych wykonywać można takie same operacje jak na zbiorach (sumy, iloczyny); można też badać zależności między takimi dziedzinami (relacja bycia poddziedzina). Poszczególne dziedziny normalne nie są jednak zbiorami w jakimś absolutnym sensie — gdy dziedzina $P_{1}$ jest elementem dziedziny $P_{2}$, to $P_{1}$ jest zbiorem w $P_{2}$. Dziedziny, które są w tym sensie zbiorami, to dziedziny zamkniete.

Zermelo wprowadza swoje Grenzzahlen (w dzisiejszej terminologii: liczby kardynalne mocno nieosiągalne) jako punkty stałe pewnej funkcji określonej przez indukcję pozaskończona.

Jesteśmy przyzwyczajeni do reprezentowania świata teoriomnogościowego w postaci kumulatywnej hierarchii zbiorów. Punktem wyjścia jest bądź zbiór pusty, bądź jakaś kolekcja atomów. Kolejne piętra hierarchii tworzone są poprzez stosowanie operacji tworzenia zbioru potęgowego (kroki następnikowe) oraz tworzenia sumy otrzymanych dotąd zbiorów (kroki graniczne). Możliwe są tu różne rozwiązania - poszczególne piętra mogą, przy jednym z takich rozwiązań zawierać inne zbiory, niż przy innym. Propozycja Zermela była następująca:

\section{Hierarchia dziedzin:}

$$
\begin{aligned}
& P_{\alpha}=U \quad \text { dla } \alpha=1 \\
& P_{\alpha}=P_{\beta} \cup\left[\wp\left(\bigcup_{0<\gamma<\alpha} P_{\gamma}\right) \backslash \bigcup_{0<\gamma<\alpha} P_{\gamma}\right] \quad \text { dla } \alpha=\beta+1, \beta \neq 0 \\
& P_{\alpha}=\bigcup_{0<\beta<\alpha} P_{\beta} \quad \text { dla } \alpha \text { granicznych. }
\end{aligned}
$$

Podstawową obserwacją w pracy [Zermelo 1930] jest ustalenie, że dziedziny normalne można przedstawić w postaci powyższych hierarchii (Ersters Entwicklungstheorem). Nadto, Zermelo podaje także ustalenia dotyczące mocy poszczególnych pięter hierarchii dziedzin (Zweites Entwicklungstheorem). Wreszcie, przedstawia reprezentację każdej dziedziny normalnej w pewnej szczególnej postaci (Drittes Entwicklungstheorem (Satz der „kanonischen” Entwicklung)).

Jeśli $\alpha$ jest liczbą kardynalną mocno nieosiagalną, to w $P_{\alpha}$ zachodzą wszystkie aksjomaty BAPUVEF.

Baza dziedziny normalnej to jej zbiór atomów. Charakterystyka dziedziny normalnej to najmniejsza liczba porządkowa, która nie jest w niej zbiorem. 
Jak już wspominaliśmy, jednym z ideałów metodologicznych powstającej na przełomie XIX i XX wieku logiki matematycznej była kategoryczna charakterystyka niektórych ważnych struktur matematycznych opisanych aksjomatycznie (liczby naturalne, liczby rzeczywiste, przestrzenie badane w geometrii, struktury algebraiczne, itd.). W paragrafie 4 omawianej pracy Zermelo podaje twierdzenia charakteryzujące dziedziny normalne z dokładnością do izomorfizmu (z uwzględnieniem dwóch parametrów: mocy bazy oraz charakterystyki dziedziny). W największym uproszczeniu, twierdzenia te można wysłowić następująco:

\title{
Erster Isomorphiesatz
}

Dwie dziedziny normalne o równolicznych bazach i tej samej charakterystyce sq izomorficzne (izomorfizm ten jest doktadnie jeden).

\section{Zweiter Isomorphiesatz.}

Dla dowolnych dwóch dziedzin normalnych o równolicznych bazach i różnych charakterystykach, jedna jest izomorficzna z odcinkiem poczatkowym drugiej.

\section{Dritter Isomorphiesatz}

Dla dowolnych dwóch dziedzin normalnych o tej samej charakterystyce, jedna jest izomorficzna z poddziedzinq drugiej.

Artykuł [Zermelo 1930] kończą uwagi dotyczące modeli teorii mnogości. Między innymi, Zermelo podaje argumentację dotycząca postulowania istnienia pozaskończonej skali liczb kardynalnych mocno nieosiagalnych, por:

\begin{abstract}
Machen wir nun die allgemeine Hypothese, daß jeder kategorisch bestimmte Bereich irgendwie auch als ,Menge” aufgefaßt werden, d.h. als Element eines (geeignet gewählten) Normalbereiches auftretten kann, so ergibt sich, daß jedem Normalbereiche ein höherer mit gleicher Basis, jedem Einheitsbereich ein höherer Einheitsbereich und damit auch jeder „Grenzzahl” $\pi$ eine größere Grenzzahl $\pi^{\prime}$ entspricht.

$[\ldots]$

„Beweisbar” aus den $\mathrm{ZF}^{\prime}$-Axiomen ist das natürlich wieder nicht, da das behauptete Verhalten aus jedem einzelnen Normalbereiche herausführt. Es muß vielmehr die Existenz einer unbegrenzten Folge von Grenzzahlen als neues axiom für die „Meta-Mengenlehre” postuliert werden, wobei noch die Frage der „Widerspruchslosigkeit” einer näheren Prüfung bedarf.
\end{abstract}

[Zermelo 1930: 46].

Na zakończenie Zermelo szydzi z anty-matematyków oraz reakcjonistów naukowych krytykujących teorię mnogości. Podkreśla, że nie należy rozumieć teorii mnogości jako teorii opisującej jakiś jeden zamierzony model. Wskazuje, że wykazana przez niego niekategoryczność jest raczej zaletą teorii mnogości, niż jej wadą, ze względu na intuicje wiązane z pojęciem zbioru.

Niektóre niepublikowane przedtem notatki Zermela (pozostawione w Nachlaß) dotyczące teorii mnogości podaje, wraz z komentarzem, artykuł [Ebbinghaus 2003].

\subsection{Próba eliminacji paradoksu Skolema}

Skolemizm był w opinii Zermela całkowicie niewłaściwym podejściem do teorii mnogości - redukcję świata zbiorów do jednego, przeliczalnego modelu Ernst Zermelo uważał za zniekształcenie (Cantorowskiej) istoty tej teorii.

Skolem nie uważał aksjomatycznej teorii mnogości za możliwą podstawę całości matematyki, przeciwnie niż Zermelo. Z kolei Zermelo uważał, że na środki dowodowe (oraz środki wyrażania) 
używane w matematyce nie można nakładać ograniczeń wtłaczających owe środki do jednego, finitystycznego systemu.

Zermelo próbował także wykazać nietrafność wczesnoskolemowskiego relatywizmu teoriomnogościowego na drodze czysto matematycznej, zamierzając udowodnić, że przyjęcie, iż mogą istnieć różne, „większe” i „mniejsze” zbiory odgrywające rolę kontinuum prowadzi do sprzeczności. Poniżej podajemy propozycję przekładu tekstu Zermela dotyczącego tej (nieudanej) próby.

\title{
RELATYWIZM W TEORII MNOGOŚCI A TAK ZWANE TWIERDZENIE SKOLEMA ${ }^{8}$ \\ ERNST ZERMELO
}

\begin{abstract}
„Kontinuum” jest zwykle w teorii mnogości definiowane jako zbiór $P$ wszystkich podzbiorów $M_{1}$ jakiegoś „przeliczalnego” zbioru $M$. Czy taka definicja jest jednak w istocie jednoznaczna, czy pojęcie „wszystkich” podzbiorów nie jest zbyt nieokreślone? Czy nie mogłyby istnieć różne stopnie tej całości, a przez to i rozmaite „modele” kontinuum; a może nawet takie kontinuum, bez utraty swoich formalnych własności, dałoby się reprezentować (zgodnie z „twierdzeniem Skolema”) przez model przeliczalny? Wtedy musiałoby być możliwe zanurzenie takiego „wątlejszego" kontinuum $K^{\prime}$ w kontinuum ,grubsze" $K$ tak, by wszystkie formalne własności przenosiły się z pierwszego z nich na drugie.
\end{abstract}

Rozważamy przeliczalny zbiór $M$ oraz podrodzinę $K^{\prime}$ rodziny $K$ wszystkich podzbiorów $N$ (w sensie kontinuum „grubszego”) o następujących własnościach:

1. Jeśli $R$ jest podzbiorem $K^{\prime}$, to zarówno jego suma $S_{R}$, jak i jego przekrój $D_{R}$ są elementami $K^{\prime}$. Innymi słowy, suma oraz przekrój dowolnie wielu (także $\infty$ wielu) zbiorów z $K^{\prime}$ są znów elementami $K^{\prime}$; elementy $K^{\prime}$ tworzą „pierścień zbiorów”.

2. Każdy element $m$ z $M$ jest elementem co najmniej jednego zbioru z $K^{\prime}$.

Niech teraz $M_{m}$ będzie przekrojem wszystkich zbiorów $N$ z $K^{\prime}$, które zawierają $m$. Tak więc, $M_{m}$ jest elementem $K^{\prime}$ i dwa takie przekroje $M_{a}$ i $M_{b}$ są albo identyczne albo rozłączne. Stąd cały zbiór $M$ jest podzielony na sumę parami rozłącznych części $M_{m}$, które z kolei same muszą być skończone lub przeliczalne. Ponadto, każdy zbiór $N$ z $K^{\prime}$ jest podzielony na takie części składowe $N_{m}$, a każda suma oraz każdy przekrój takich $N_{m}$ musi, na mocy 1., znów być elementem $K^{\prime}$.

Jeśli teraz przez $T$ oznaczymy zbiór wszystkich (różnych między sobą) $M_{a}$, to każdy element $K^{\prime}$ wzajemnie jednoznacznie odpowiada pewnemu podzbiorowi $T$, a $K^{\prime}$ jest równoważne z rodziną $U T$ wszystkich podzbiorów $T$. Zbiór części, na które przeliczalny zbiór $M$ może zostać podzielony jest albo skończony albo sam jest przeliczalny, tj. równoważny ze zbiorem $M$, a stąd pseudo-kontinuum $K^{\prime}$ samo jest albo skończone albo równoważne z $K^{\prime} \sim U T \sim U M=K$, tj. równoważne z wyjściowym (nieprzeliczalnym) kontinuum $K$. Jest zatem niemożliwe, aby kontinuum było reprezentowane w modelu przeliczalnym, musi ono być skończone. ,Twierdzenie Skolema" prowadzi więc do interesującego wniosku, że zbiory nieskończone mogą być zrealizowane w modelach skończonych — wniosku nie bardziej paradoksalnego niż niektóre inne już z tego pięknego twierdzenia wyprowadzone konsekwencje. W ten sposób także ideał ,intuicjonizmu”, wyrzucenie z matematyki niekończoności, byłby bliższy realizacji, wspólnie z celem „formalizmu”, którym jest, jak wiadomo, dowód niesprzeczności. Znaną jest rzeczą, że z absurdalnych przesłanek dowieść można wszystkiego. A więc także niesprzeczności dowolnego systemu zdań.

\footnotetext{
${ }^{8}$ Oryginał tego tekstu, pod tytułem Der Relativismus in der Mengenlehre und der sogenannte Skolem'sche Satz znajduje się w Nachlaß Zermela w bibliotece Universität Freiburg; został on opublikowany, wraz z angielskim tłumaczeniem, w artykule: Dirk van Dalen, Heinz-Dieter Ebbinghaus Zermelo And the SKolem Paradox, The Bulletin of Symbolic Logic, Volume 6, Number 2, 2000, 145-161 (zob. [van Dalen, Ebbinghaus 2000]). Niniejsze thumaczenie zaproponowano na podstawie tej właśnie publikacji.
} 
D. van Dalen oraz H.D. Ebbinghaus pokazują, w cytowanym wyżej artykule, gdzie tkwi błąd w uzasadnieniu podanym przez Zermela. Polega on mianowicie na nieuprawnionym założeniu dotyczącym domkniętości modelu na dowolne sumy oraz iloczyny:

To see where the refutation breaks down, the modern reader might visualize the argument by thinking of a countable elementary submodel $V^{\prime}$ of a standard model $V$ of $Z F$, he would take $M$ to be $\omega$, and pick for $K$ and $K^{\prime}$ the respective continua in $V$ and $V^{\prime}$. Now, translated to this situation, Zermelo's proof makes use of arbitrary intersections and unions of subsets of $K^{\prime}$, i.e., arbitrary in the sense of $V$, where for a correct argument 'arbitrary' would have to mean 'in the sense of $V^{\prime}$. The strong closure property, however, is not available. Should we allow it, then we know that elementary equivalence cannot apply.

So altogether Zermelo's refutation amounts to a proof of the set-theoretical statement saying that, given a denumerable set $M$, any subset of the powerset $K$ of $M$ that is closed under arbitrary unions and intersections (and under complements with respect to $M$ ) and whose union is $M$, either is finite or of the same cardinality as $K$.

[van Dalen, Ebbinghaus 2000: 156].

Cytowani autorzy argumentują także, że nietrafne interpretowanie uzyskanego przez Zermela wyniku matematycznego jako eliminacji paradoksu Skolema mogło mieć swoje źródło w jego postawie epistemologicznej wobec teorii mnogości — Zermelo wierzył w istnienie absolutnej hierarchii zbiorów. ${ }^{9}$

\footnotetext{
${ }^{9}$ W grudniu 2005 roku Profesor Jan Zygmunt przedstawiał, na Seminarium Opolskim Profesora Janusza Czelakowskiego związki między uzasadnieniami podanymi wyżej przez Zermela a twierdzeniem głoszącym, iż każda nieskończona $\sigma$-algebra Boole'a jest nieprzeliczalna (a dokładniej, mocy kontinuum).
} 


\section{Logika infinitarna Zermela}

Wydaje się, że wśród inspiracji dla projektu logiki infinitarnej Zermela jako istotne wymienić można następujące czynniki:

- poglądy Zermela na naturę nieskończoności; przekonanie, że matematyka jest logikq nieskończoności;

- przekonanie Zermela o fundamentalnej dla całości matematyki roli (jego systemu) teorii mnogości; w szczególności, traktowanie formuł oraz dowodów jako (dobrze ufundowanych) tworów z hierarchii kumulatywnej zbiorów (przedstawionej w artykule z 1930 roku);

- odrzucenie skolemizmu; przekonanie, że ani przedmiotu badań teorii mnogości nie można zredukować do pojedynczego jej modelu, ani nie można zaakceptować finitystycznego punktu widzenia w procedurze dowodzenia twierdzeń matematycznych;

- przekonanie, że nie należy nakładać ograniczeń na postać formuł w aksjomacie wyróżniania (w szczególności, nie ograniczać się do języka pierwszego rzędu).

Zermelo był przede wszystkim (jeśli nie wyłącznie) matematykiem. Na tematy filozoficzne wypowiadał się oszczędnie i z dystansem, zawsze podkreślając, iż interesują go głównie matematyczne aspekty podejmowanych rozważań. Pewne uwagi natury filozoficznej znaleźć można w jego Tezach o nieskończoności oraz w wykładach prowadzonych w Warszawie wiosną 1929 roku. ${ }^{10}$

W Nachlaß znajdują się Tezy o nieskończoności w matematyce. Poniżej cytujemy ten krótki tekst. Uwagi na jego temat znaleźć można np. w pracy [Taylor 2002] oraz [van Dalen, Ebbinghaus 2000]. Jest kwestią nie do końca przesądzoną, z jakiego okresu pochodzi ta notatka — czy z roku 1921 (jak głosi umieszczona na niej data), czy z okresu o wiele późniejszego (co - zdaniem niektórych sugeruje dopisek ołówkiem „42”). Wydaje się istotne, że poglądy zawarte w tej notatce były przez Zermela przedstawiane podczas jego wykładów w 1929 roku w Warszawie.

\section{ZERMELO 17. Juli 1921}

\section{Thesen über das Unendliche in der Mathematik}

I) Jeder echte mathematische Satz hat "infinitären" Charakter, d.h. er bezieht sich auf einen unendlichen Bereich und ist als eine Zusammenfassung von unendlich vielen "Elementarsätzen" aufzufassen.

II) Das Unendliche ist uns in der Wirklichkeit weder physich noch psychisch gegeben, es muß als "Idee" im Platonischen Sinne erfaßt und "gesetzt" werden.

III) Da aus finitären Sätzen niemals infinitäre abgeleitet werden können, so müssen auch die "Axiome" jeder mathematischen Theorie infinitär sein, und die "Widerspruchslosigkeit" einer solchen Theorie kann nicht anders "bewiesen" werden als durch Aufweisung eines entsprechenden widerspruchsfreien Systems von unendlich vielen Elementarsätzen.

IV) Die herkömmliche "Aristotelische" Logik ist ihrer Natur nach finitär und daher ungeeignet zur Begründung der mathematischen Wissenschaft. Es ergibt sich daraus die Notwendigkeit einer erweiterten "infinitären" oder "Platonischen" Logik, die auf einer Art infinitärer "Anschauung" beruht — wie z.B. in der Frage des "Auswahlaxioms" —, aber paradoxerweise gerade von den "Intuitionisten" aus Gewohnheitsgründen abgelehnt wird.

V) Jeder mathematische Satz ist aufzufassen als eine Zusammenfassung von (unendlich vielen) Elementarsätzen, den “Grundrelationen”, durch Konjunktion, Disjunktion und Negation, und jede Ableitung eines Satzes aus anderen Sätzen, insbesondere jeder "Beweis" ist nichts anders als eine "Umgruppierung" der zugrunde liegenden Elementarsätze.

\footnotetext{
${ }^{10}$ Być może, ciekawym zadaniem dla jakiegoś historyka matematyki byłoby przygotowanie artykułu Zermelo in Warschau...
} 
Jak rozumieć te tezy? Należy pamiętać, że Zermelo nigdy nie używał języków sformalizowanych w takim sensie, jak robimy to dzisiaj. Podobnie z systemem logiki, zob. często w różnych opracowaniach cytowany fragment z omówionego wyżej artykułu [Zermelo 1929], a odnoszący się do aksjomatyki, którą Zermelo przedstawił w 1908 roku:

Eine allgemein anerkannte „mathematische Logik”, auf die ich mich hätte berufen können, gab es damals noch nicht — so wenig wie heute, wo jeder Grundlagen-Forscher seine eigene Logistik hat.

[Zermelo 1929: 340].

W metaforycznym sformułowaniu Zermela, „matematyka to logika nieskończoności”. Takimi słowami kończy się pozostawiona w Nachlaß notatka odnosząca się do czwartego (Endliche und unendliche Bereiche) z dziewięciu wykładów wygłoszonych przez niego w dniach od 27 maja do 8 czerwca 1929 roku w Warszawie:

Die wahre Mathematik ist vielmehr ihrem Wesen nach infinitistisch und auf die Annahme unendlicher Bereiche gegründet; sie kann geradezu als die 'Logik des Unendlichen' bezeichnet werden.

[Zermelo 1929a]; cytat za [Moore 1980: 136].

Wydaje się, że najważniejszy w Tezach jest ich aspekt ontologiczny — matematyka zajmuje się przede wszystkim strukturami nieskończonymi. Wszelkie próby wyrażania zależności matematycznych za pomocą skończonych środków językowych były dla Zermela jedynie swego rodzaju aproksymacjami tych pierwszych przez drugie.

Wedle tezy I, nieskończonościowa natura stwierdzeń matematycznych polega na tym, że odnoszą się one do dziedzin nieskończonych i powinny być ujmowane jako kolekcje nieskończenie wielu stwierdzeń elementarnych.

Nieskończoność powinna być ujmowana jako idea w sensie platońskim — nieskończoność nie jest nam dostępna ani fizycznie, ani psychicznie; taka jest treść tezy II.

Ponieważ, twierdzi Zermelo w tezie III, ze zdań o charakterze skończonościowym nie można wyprowadzić zdań o charakterze nieskończonościowym (a takie są, w myśl tezy I, stwierdzenia matematyczne), zatem również aksjomaty wszelkich teorii matematycznych muszą mieć charakter nieskończonościowy. Niesprzeczność takich teorii nie może być wykazana inaczej niż poprzez wskazanie wolnego od sprzeczności systemu nieskończenie wielu zdań elementarnych [czyżby odpowiadało to, używając współczesnej terminologii, sformułowaniu: poprzez podanie diagramu modelu?].

Logika tradycyjna (Arystotelesowska) ma, ze swej natury, charakter skończonościowy i nie nadaje się do ugruntowania wiedzy matematycznej — twierdzi Zermelo w tezie IV. Powstaje potrzeba skonstruowania rozszerzonej logiki infinitarnej, „Platońskiej”, która dotyczyłaby oglądu o charakterze nieskończonościowym, takim z jakim mamy do czynienia na przykład w przypadkach użycia aksjomatu wyboru. Zermelo ubolewa, że pomysł takiej logiki odrzucany jest przez intuicjonistów z powodów, jak pisze, przywiązania do nawyków.

Każde stwierdzenie matematyczne jest kolekcją nieskończenie wielu stwierdzeń elementarnych łączonych negacjami i koniunkcjami oraz alternatywami. Każde wyprowadzenie jakiegoś zdania matematycznego z innych (w szczególności, każdy dowód) jest niczym innym, jak pewnym przegrupowaniem branych pod uwagę stwierdzeń elementarnych. Oto, jak w przybliżeniu oddać można chyba treść tezy V.

Komentarze na temat Tez o nieskończoności znaleźć można np. w: [Taylor 2002], [van Dalen, Ebbinghaus 2000]. Poglądy Zermela na filozofię matematyki omawiane są m.in. również np. w [Taylor 1993]. 
Ostatnia z opublikowanych prac Zermela (tj. [Zermelo 1935]) zawiera propozycje zastosowania wyników przedstawionych w omówionym wyżej artykule [Zermelo 1930] do precyzacji podstawowych pojęć logicznych (w ówczesnej terminologii: do Beweistheorie).

Punktem wyjścia jest relacja wynikania:

Wir sagen , $p$ folgt aus $a, b, c, \ldots$ ” und schreiben $a, b, c, \ldots \rightarrow p$, wenn mit der Wahrheit von $a, b, c, \ldots$ auch die von $p$ gesetzt sein soll, und nennen den Komplex $a, b, c \ldots$ den „Grund”, den Satz $p$ die „Folge” und den dieser Formel innenwohnenden Sinn die „Begründung des Satzes $p$.

[Zermelo 1935: 139].

Zermelo dowodzi, że jeśli wprowadzona wyżej relacja wynikania jest dobrze ufundowana, to zachowuje ona prawdziwość. Podaje dalej następującą definicję pojęcia dowodu, odwołująca się do wspomnianej relacji wynikania (i odpowiadająca — jak się wydaje — temu, co matematycy (nie logicy) rozumieją przez dowód (matematyczny)):

Ein (direkter) Beweis ist ein durch Folgerung (Begründung) wohlfundiertes System von Sätzen, zu denen der zu beweisende gehört, und dessen Basis aus lauter wahren Sätzen besteht, welche die Voraussetzung des Satzes bilden.

[Zermelo 1935: 140].

Typowym przykładem takiego „dowodu” 11 jest, wedle Zermela, wnioskowanie oparte na zasadzie indukcji:

Das typische Beispiel eines solchen „Beweises” bildet das Schlußverfahren der „vollständigen Induktion". Das System $S$ besteht hier aus Sätzen $P_{n}$, welche den Zahlen der natürlichen Zahlenreihe eineindeutig entsprechen, wobei für jedes $n$ die Folgerung $p_{n-1}$ erwiesen sei und die Gültigkeit des Satzes $p_{1}$ (des einzigen der Basis) angenommen wird. Dieses System ist „wohlfundiert", denn jedes Teilsystem $T$ enthält ein $p_{n}$ mit kleinstem Index, sodaß das entsprechende $P_{n-1}$ nicht mehr zu $T$ gehört. Wesentlich für die Gültigkeit dieses Schlußverfahrens ist also die Eigenschaft der Zahlenreihe, daß unter beliebig vielen Zahlen eine die kleinste ist und daß jeder Zahl $n$ (außer der ersten) eine unmittelbar vorangehende $n-1$ entspricht.

[Zermelo 1935: 140].

Dość szczegółowa analiza propozycji Zermela przedstawiona została w pracy: R. Gregory Taylor: Zermelo's Cantorian Theory of Systems of Infinitely Long Propositions. The Bulletin of Symbolic Logic Volume 8, Number 4, 2002, 478-515 (zob. [Taylor 2002]). Poniżej posłużymy się wybranymi ustaleniami właśnie z tej pracy, korzystając także z notacji tam proponowanej.

Każda teoria matematyczna, pisze Zermelo, odnosi się do jakiejś (w ogólności, nieskończonej) dziedziny elementów (obiektów takich, jak np. liczby, punkty, figury, itd.). Owo uniwersum nazywa dziedzinq podstawowa; oznaczmy ją przez $D$. Między elementami $D$ zachodzić mogą różnorakie związki, np.:

$a<b, a+b=c, a$ leży na prostych $b$ oraz $c$.

Takie związki nazywa Zermelo Grundrelationen; oznaczmy ogół wszystkich relacji, które brane są pod uwagę przez $R$. $\mathrm{Z}$ tych relacji podstawowych otrzymujemy dalsze relacje, poprzez zastosowania operacji negacji oraz — stosowanych do dowolnej, skończonej lub nieskończonej liczby argumentów - operacji koniunkcji i alternatywy. Ogół relacji podstawowych oznaczmy przez $C_{R}$.

\footnotetext{
${ }^{11}$ Zermelo stanowczo nadużywa cudzysłowów, nie tylko w przytoczonym cytacie. Nie udało mi się dotąd rozszyfrować, co nim kieruje w tej manierze.
} 
Zermelo zakłada (nie całkiem jawnie), że dysponujemy jakąś relacją „bycia podwyrażeniem”. O relacji tej zakłada, iż pozwala ona dobrze ufundować ogół wszystkich wyrażeń tworzonych z relacji podstawowych poprzez stosowanie dowolnie dużą liczbę razy wspomnianych wyżej operacji. Tak więc, ogół wyrażeń tworzy hierarchię, wzorowaną na hierarchii zbiorów z artykułu [Zermelo 1930]; oznaczmy tę hierarchię przez $H_{D, R}$. Pewne poddziedziny tej hierarchii mogą być zbiorami (elementami stosownych, wyższych pięter hierarchii); niektóre zaś — dziedzinami otwartymi (w sensie podanym w [Zermelo 1930]). Ta dychotomia odpowiada, wedle Zermela, różnicom w ogólności teorii matematycznych:

In dieser allgemeinen Form läßt sich jede auf einen bestimmten Urbereich von Elementen und bestimmte Grundrelationen gegründete mathematische Disziplin darstellen, so die Arithmetik der rationalen, algebraischen Zahlen und Funktionen, die Analysis der reellen und komplexen Zahlen und Funktionen, ebenso die Geometrie jedes Raumes von gegebener Dimensionenzahl, auch die Mengenlehre eines gegebenes „Normalbereiches” [...] Etwas anders verhält es sich dagegen mit der Theorie der „offenen” Bereiche, wie der ,allgemeinen Körpertheorie”, der allgemeinen Geometrie oder der allgemeinen, über alle Normalbereiche ausgedehnten Mengenlehre.

[Zermelo 1935: 142].

Podsumujmy; mamy dotąd następujące konstrukcje:

Relacje na $D: R=\left\{R_{1}^{n_{1}}, \ldots, R_{j}^{n_{j}}\right\}$.

Relacje podstawowe na $D$ : kolekcja $C_{R}$ zdań atomowych postaci $R_{i}^{n_{i}} a_{1} \ldots a_{n_{i}}$ (dla $R_{i}^{n_{i}} \mathrm{z} R$ oraz $\left.a_{1}, \ldots, a_{n_{i}} \mathrm{z} D\right)$.

Hierarchia wyrażeń: $H_{D, R}$ (bazą jest $C_{R}$ ).

Następne konstrukcje wprowadzają pojęcia semantyczne. Gdy dany jest jakikolwiek podział rodziny $C_{R}$ zdań atomowych (relacji podstawowych, w terminologii Zermela), to podział taki daje się jednoznacznie rozszerzyć na wszystkie zdania hierarchii $H_{D, R}$ :

- ustalamy (w sposób naturalny), jak wartość logiczna negacji, koniunkcji, alternatywy wyznaczona jest przez wartości logiczne argumentów tych funktorów;

- zauważamy, że gdyby istniały zdania w $H_{D, R}$ o nieustalonej jednoznacznie wartości logicznej, to tworzyłyby one poddziedzinę, powiedzmy $S$; w $S$ musi znajdować się element pierwszy (co wynika z dobrego ufundowania hierarchii wyrażeń), np. $t_{0}$; nie należy on do bazy $C_{R}$ oraz zbudowany jest wyłącznie z wyrażeń należących do $H_{D, R}-S$ (poprzez użycie operacji negacji, koniunkcji, alternatywy), ale owe wyrażenia mają, z założenia, jednoznacznie ustalone wartości logiczne, otrzymujemy więc sprzeczność — nie mogą istnieć w $H_{D, R}$ zdania, które nie miałyby jednoznacznie ustalonej wartości logicznej (przy danym wyjściowym podziale zdań atomowych z $C_{R}$ na prawdziwe i fałszywe).

Oznaczmy przez $\Pi$ ogół wszystkich podziałów prawdziwościowych na $C_{R}$.

Za równoważne (logicznie) uważa Zermelo te zdania, które przy każdym podziale prawdziwościowym wyrażeń bazowych należą do dokładnie takich samych klas podziałów prawdziwościowych całej hierarchii wyrażeń (tj. w każdym z takich podziałów przyjmują te same wartości logiczne). Pokazuje, że w rozważanym systemie ${ }^{12}$ zachodzą prawa de Morgana: negacje (dowolnych) koniunkcji są równoważne alternatywom negacji, negacje (dowolnych) alternatyw są równoważne koniunkcjom negacji.

\footnotetext{
${ }^{12}$ Zdajemy sobie sprawę, że stosowanie w tym wypadku słowa „system” jest nadużyciem wedle współczesnych standardów - Zermelo nie precyzuje całkiem jasno języka, w którym pracuje.
} 
Pojęcie wynikania logicznego definiuje Zermelo poprzez podziały prawdziwościowe. Klasa wszystkich zdań z hierarchii $H_{D, R}$, które są prawdziwe przy danym podziale prawdziwościowym jest poddziedziną $H_{D, R}$. Dla danego zdania $s$, przekrój $V^{*}(s)$ wszystkich takich klas (indeksowany elementami $\Pi)$, których elementem jest zdanie $s$ zawiera także wszystkie te zdania, które są prawdziwe, o ile $s$ jest prawdziwe. Tak więc, przekrój ten odpowiada klasie wszystkich zdań, które wynikaja logicznie z $s$.

Podobnie, przekrój $U^{*}(s)$ wszystkich klas (poddziedzin $H_{D, R}$ ) złożonych ze zdań fałszywych i których elementem jest dane zdanie $s$, zawiera te wszystkie zdania, z których $s$ wynika logicznie. Zermelo nazywa $V^{*}(s)$ der Folgebereich von $s$, a $U^{*}(s)$ der Ursprungsbereich von $s$.

Zdania równoważne logicznie ze zdaniem $s$ to zdania wspólne der Folgebereich von s oraz der Ursprungsbereich von s:

$$
A^{*}(s)=V^{*}(s) \cap U^{*}(s)
$$

Zermelo podaje następujący przykład:

Ist z.B. $s$ ein „Axiomensystem” einer auf die Grundrelationen gegründeten mathematischen Theorie, z.B. der Arithmetik oder der euklidischen Geometrie, so umfaßt $A^{*}(s)$ alle äquivalenten Axiomensysteme, $V^{*}(s)$ alle Sätze der aus $s$ fließenden Theorie, insbesondere alle allgemeineren Axiomensysteme, und $U^{*}(s)$ alle spezielleren Axiomensysteme.

[Zermelo 1935: 144].

Pozwolimy sobie na jeszcze jeden — nieco dłuższy — cytat z pracy [Zermelo 1935]; oddaje on chyba wiernie poglądy Zermela na związek między wprowadzonym wyżej pojęciem wynikania logicznego a wyprowadzalnością (dowodliwością) jednych zdań z innych, tak jak — przypuszczamy — mogli wyprowadzalność taką rozumieć matematycy, budując dowody matematyczne: ${ }^{13}$

Liegt ein Satz $t$ im Folgebereich $V^{*}(s)$, ,folgt” also aus $s$, so ist er auch ,syllogistisch ableitbar” aus $s$, und zwar bereits innerhalb des gemeinsamen „Wurzelbereiches” oder „Definitionsbereiches” $W(s, t)$ von $s$ und $t$. Es ist dies der Durschnitt aller $s$ und $t$ enthaltenen „Wurzelbereiche" $W$, nämlich aller solchen, die mit jedem in ihnen enthaltenden abgeleiteten Satze auch seine sämtlichen „Wurzeln” enthalten, d.h. mit jeder Negation $\bar{a}$ den verneinten Satz $a$, und mit jeder Koniunktion oder Disjunktion ihre sämtlichen Glieder. Dann entspricht jeder beliebigen Wahrheitsverteidigung des Gesamtsystems auch eine solche von $W(s, t)$, und jeder Durschnitt $V^{\prime}$ mit einem Wahrheitsbereiche $V$ enthält entweder $s$ nicht oder er enthält zugleich auch $t$. Der Bereich $W$ enthält alle zur Ableitung von $t$ erforderlichen Zwischensätze, und ihre „Wertung”, ihre Wahrheitsverteidigung, erfolgt in ihm nach den syllogistischen Regeln.

Demnach wäre also jeder aus $s$ folgende Satz auch „,beweisbar”, aber zunächst nur im absoluten, „infinitistischen” Sinne. Ein solcher „Beweis” enthält zumeinst unendlich viele Zwischensätze, und es ist noch nicht gesagt, in wie weit und durch welche Hilfsmittel er auch unserem endlichen Verstande eileuchtend gemacht werden kann. Im Grunde ist jeder mathematische Beweis, z.B. das Schlußverfahren der „vollständigen Induktion” durchaus ,infinitistisch” und doch vermögen wir ihn einzusehen. Feste Grenzen der Verständlichkeit gibt es hier augenscheilich nicht.

[Zermelo 1935: 144].

Ze słów tych widać dość wyraźnie, jak sądzimy, że Zermelo chciał rozumieć pojęcie dowodu (matematycznego) w jakimś sensie absolutnym, jako wyznaczone jedynie poprzez semantyczne własności zdań. Przeprowadzane w praktyce dowody matematyczne byłyby swego rodzaju aproksymacjami tak absolutnie rozumianych dowodów.

\footnotetext{
${ }^{13}$ Pojęcie dowodu matematycznego jest pojęciem psychologicznym; nadto w jego charakterystyce uwzględniać należy dalsze (oprócz logicznych, odnoszących się do prawdy i wynikania logicznego) pojęcia, np. socjologicznej natury.
} 
Artykuł [Zermelo 1935] kończą uwagi na temat kategoryczności. Są one warte porównania, jak sądzimy, z dotyczącymi tej samej problematyki ustaleniami Tarskiego formułowanymi w tym samym mniej więcej czasie (np. [Tarski 1934]).

Podsumujmy: semantyczna charakterystyka teorii matematycznych u Zermela bierze pod uwage $\Pi$ - niepustą rodzina podziałów prawdziwościowych na $C_{R}$. W terminach podziałów prawdziwościowych definiuje się wynikanie logiczne.

Teoria matematyczna u Zermela może być rozumiana jako układ:

$$
T=\left\langle D, C_{R}, \Pi\right\rangle .
$$

$\operatorname{Val}_{\Pi}$ jest klasą wszystkich zdań z $H_{D, R}$, które są П-prawdziwe, tj. prawdziwe dla wszystkich podziałów prawdziwościowych z $\Pi$.

Zarówno Val $_{\Pi}$ jak i $H_{D, R}$ są dziedzinami otwartymi.

Dla $\alpha$ mocno nieosiagalnych dziedziny

$$
\operatorname{Val}_{\Pi} \cap P_{\alpha}
$$

są domkniętymi aproksymacjami $T$ (tutaj $P_{\alpha}$ jest piętrem o indeksie $\alpha$ w hierarchii zbiorów, której bazą jest ogół relacji podstawowych $C_{R}$. Należy rozumieć, że hierarchia wszystkich wyrażeń, tj. $H_{D, R}$ jest poddziedziną hierarchii zbiorów.

Zdanie Zermela $\wedge\left(\operatorname{Val}_{\Pi} \cap P_{\alpha}\right)$ jest przykładem prawdziwego, ale niedowodliwego zdania w systemie $\left\langle P_{\alpha}, \prec\right\rangle$. Tutaj $\prec$ jest relacją syntaktyczną, odpowiadająca wspomnianej wyżej relacji bycia częścią (podformułą). ${ }^{14}$

\section{Zermelo a Gödel}

Zachowała się niewielka korespondencja między Zermelą a Gödlem. ${ }^{15}$ Wiemy też, że spotkali się i dyskutowali w Bad Elster.

W okresie między początkiem wieku XX (około powstania Principia Mathematica), a przed jego połową (około powstania Grundlagen der Mathematik) powoli, stopniowo następowała zmiana paradygmatu uprawiania logiki matematycznej. Zermelo, jak już podkreślaliśmy, był matematykiem sam odżegnywał się od ,filozofowania”, zwracał uwagę na brak powszechnie uznanego, stabilnego systemu logistycznego (następował zmierzch teorii typów, standard logiki pierwszego rzędu dopiero się wyłaniał). Wreszcie, być może również ze względów ambicjonalnych, Zermelo uważał, że (jego) aksjomatyczna teoria mnogości jest dyscypliną na tyle fundamentalną, że pozwala na rekonstrukcję wszelkich rozważań matematycznych. Rozważania nad teorią dowodu (w logicznym sensie tego terminu) były chyba dla Zermela czymś podrzędniejszym, drugoplanowym wobec prymarnego celu, jakim było uprawianie matematyki i ugruntowanie matematyki w niej samej (w aksjomatycznej teorii mnogości).

Zermelo spotkał się z Gödlem w Bad Elster, gdzie obaj wygłaszali wykłady 15 września 1931 roku. Tekst wykładu Gödla nosi tytuł Über die Existenz unentscheidbarer arithmetischer Sätze in den formalen Systemen der Mathematik; nie został on opublikowany w sprawozdaniach z posiedzenia. Z kolei, tekst Zermela: Über Stufen der Quantifikation und die Logik des Unendlichen. został opublikowany w tych sprawozdaniach — Jahresbericht der Deutschen Mathematiker-Vereinigung 41, 1932, 85-92 (zob. [Zermelo 1932]). Jak wiadomo z korespondencji Zermela, ${ }^{16}$ pierwszy akapit opublikowanego tekstu nie był wygłaszany - Zermelo dodał go dopiero w druku, podobno wstrzymał się z wygłoszeniem poniższych uwag, aby nie zaszkodzić rozpoczynającemu karierę naukową Gödlowi:

\footnotetext{
${ }^{14}$ Należy rozumieć, że relacja ta ma jakąś teoriomnogościową reprezentację.

${ }^{15}$ Zob. przedruki np. w: [Grattan-Guinness 1979], [Dawson 1985], [Buldt et al. 2002].

${ }^{16}$ Zob. np. [Peckhaus 1990].
} 
Von der Voraussetzung ausgehend, daß alle mathematischen Begriffe und Sätze durch ein festes endliches Zeichensystem darstellbar sein müßten, gerät man schon beim arithmetischen Kontinuum unausweichlich in die bekannte „Richardsche Antinomie”, wie sie neuerdings, nachdem sie schon lange erledigt und begraben schien, im Skolemismus, der Lehre, daß jede mathematische Theorie, auch die Mengenlehre, in einem abzählbaren Modell realisierbar sei, ihre fröhliche Auferstehung gefunden hat. Aus widerspruchsvollen Prämissen kann man bekanntlich alles beweisen, was man will; aber auch die seltsamsten Konsequenzen, die Skolem und andere aus ihrer Grundannahme gezogen haben, z.B. die „Relativität des Teilmengen- wie des Äquivalenzbegriffs, scheinen noch nicht genügt zu haben, um gegen eine Lehre bedenklich zu stimmen, die für manche bereits die Kraft eines über alle Kritik erhabenen Dogmas angenommen zu haben scheint. Eine gesunde „Metamathematik”, eine wahre „Logik des Unendlichen”, wird aber erst möglich sein durch eine grundsätzliche Abkehrung von der oben charakterisierten Voraussetzung, die ich als ,finitistische Vorurteil” bezeichnen möchte. Überhaupt sind nicht wie manche annehmen, „Zeichenverbindungen” der wahre Gegenstand der Mathematik, sondern begrifflich-ideale Relationen zwischen den Elementen einer begrifflich gesetzten unendlichen Mannigfaltigkeit, und unsere Zeichensysteme sind dabei immer nur unvollkommene und von Fall zu Fall wechselnde Hilfsmittel unseres endlichen Verstandes, des Unendlichen, das wir nicht unmittelbar und intuitiv „überblicken” oder erfassen können, wenigstens in schrittweiser Annäherung Herr zu werden. Im folgenden soll nun versucht werden, die Grundlagen einer ,mathematischen Logik” zu entwickeln, die frei vom „,finitistischen Vorurteil” und von inneren Widersprüchen Raum genug bieten soll fü die gesamte bisherige Mathematik und ihre fruchtbare Weiterentwicklung unter Verzicht auf alle willkürlichen Verbote und Einschränkungen.

[Zermelo 1932: 85].

W dalszej części tej noty Zermelo przedstawia, w szkicowej formie, omówione już wyżej propozycje rozumienia pojęcia dowodu (matematycznego); zacytujmy zdanie wyróżnione w tekście przez Autora:

Denn ein mathematischer „Beweis” ist überhaupt nichts anderes als ein durch Quantifikation wohlfundiertes System von Sätzen, daß ohne Verletzung der syllogistischen Regeln nicht in zwei Klassen, ,wahre” und ,falsche” zerlegt werden kann, wobei die Voraussetzungen zur ersten und der zu beweisende Satz zur zweiten gehörte.

[Zermelo 1932: 87].

Używany przez Zermela w tym tekście termin poziomy kwantyfikacji (Stufen der Quantifikation) eksplikowany jest przez odwołanie się do indeksów pięter hierarchii zbiorów (pamiętajmy, że Zermelo proponował traktować zdania występujące w dowodach matematycznych jako konstrukcje teoriomnogościowe).

Zermelo porównuje też swoją propozycję z opublikowanymi właśnie wynikami Gödla dotyczącymi niezupełności:

Für unseren Stanpunkt ist also jeder ,wahre” Satz zugleich auch „, beweisbar”, sowie jeder durch ein wohlfundiertes Satzsystem $S$,definierbare” Satz zugleich auch „entscheidbar”, una zwar ohne daß ein Übergang ze einer höheren Quantifikationsstufe erforderlich wäre. Es gibt keine (objektiv) ,unentscheidbaren” Sätze. Demgegenüber versuchte Herr Gödel (Wiener Monatshefte Bd. 38, S. 173) das Gegenteil zu beweisen, indem er für ein „PM-System” von beschränkter (nämlich endlicher) Quantifikationsstufe einen Satz A herzuleiten suchte, der nachweislich (wenigstens in diesem System) unentscheidbar sein soll. Der Gödelsche Beweis kommt aber nur dadurch zustande, daß bei ihm die „,finitistische” Einschränkung lediglich auf die „,beweisbaren” 
Sätze des Systems, nicht auf alle dem System angehörigen Sätze angewendet wird. So bilden nur die ersteren, nicht die letzteren eine abzählbare Menge, und es muß natürlich in diesem Sinne „unentscheidbare” Sätze geben. Aber gerade der von G. als Beispiel eines „unentscheidbaren” konstruierte Satz erweist sich, wie er selbst feststellt, nachher doch wieder als „,beweisbar”, wenn auch nicht im Sinne der ursprünglichen Definition. Diese ganze Argumentation kann also m.E. nur dann dienen, die Unzulänglichkeit jeder, ,finitistischen” Beweistheorie zu erhärten, ohne doch ein Mittel zur Behebung dieses Übelstandes an die Hand zu geben. Die eigentliche Frage, ob es absolut-unentscheidbare Sätze, absolut-unlösbare Probleme in der Mathematik gibt, wird durch solche relativistischen Betrachtungen in keiner Weise berührt.

[Zermelo 1932: 87].

W 1931 roku miała też miejsce wymiana listów między Zermelą a Gödlem. ${ }^{17}$ Zermelo w krótkim liście z 21 września 1931 pisze Gödlowi, iż znalazł lukę w jego dowodzie istnienia zdań prawdziwych, acz niedowodliwych w systemach typu PM. Odpowiedź Gödla (z 12 października 1931) jest dość obszerna, zawiera w grzecznej formie wyjaśnienia wskazujące, gdzie Zermelo błędnie rozumie myśl Gödla (w największym skrócie: błąd Zermela polegał na nieodróżnianiu formuł od nazw formuł). Na marginesie dodajmy, że w tymże liście znajduje się uwaga Gödla dotycząca niedefiniowalności predykatu prawdziwości dla formuł języków określonych teorii w języku tychże teorii (a więc to, co jest treścią twierdzenia wiązanego z nazwiskiem Tarskiego). Gödel wyraża też zainteresowanie artykułem [Zermelo 1930] (Zermelo sam zwracał się do niego z komplementem, że uważa go za jednego z nielicznych, którzy z artykułu mogliby odnieść pożytek, rozwijając zawarte w nim idee). Odpowiedź Zermela jest (29 października 1931) zwięzła i na tym kończy się, o ile wiadomo, ich korespondencja. Zacytujmy znaczący, naszym zdaniem, fragment z tego listu:

Was versteht man unter einem Beweis? Ganz allgemein versteht man darunter ein System von Sätzen derart, daß unter Annahme der Prämissen die Gültigkeit der Behauptung einsichtig gemacht werden kann. Und es ist nur noch die Frage, was alles ,einsichtig” ist? Jedenfalls nicht bloß, und das zeigen Sie gerade selbst, die Sätze irgend eines finitistischen Schemas, das ja auch in Ihrem Falle immer wieder erweitert werden kann. Aber damit wären wir eigentlich einig: nur daß ich eben von vorn herein ein allgemeines Schema, das nicht erst erweitert zu werden braucht, zugrunde lege. Und in diesem System sind dann auch wirklich alle Sätze ,entscheidbar”.

Z listu Zermela do Gödla [29 X 1931].

Zermelo zwraca uwagę, zdania nierozstrzygalne (w sensie Gödla) w jakimś systemie są (czego również Gödel jest świadom) rozstrzygalne w systemie mocniejszym; ale ów mocniejszy system powstaje z wyjściowego nie poprzez dodawanie nowych zdań, ale poprzez rozszerzenie możliwości dowodowych.

\section{Also, doch ist die Zeit angekommen...}

W czasie, gdy Zermelo przedstawiał projekt swojej logiki infinitarnej, nie miał ów projekt szans na szybki rozwój. Dopiero po dwóch dekadach rozpoczęły się intensywne, systematyczne badania dotyczące logik infinitarnych.

W przygotowywanej rozprawie postaramy się wskazać na niektóre fakty z historii logiki matematycznej, które pokazują, że program Zermela logiki infinitarnej stanowi wartościowy wkład do rozwoju tej dyscypliny.

W odpowiedzi na list Paula Bernaysa z powinszowaniami z okazji 70 urodzin Zermelo pisał (1 października 1941) m.in.:

\footnotetext{
${ }^{17}$ Teksty znaleźć można także w Collected Works Gödla, tom IV, 2003, 418-431.
} 


\begin{abstract}
Man wird eben immer einsamer, ist aber umso dankbarer für jedes freundliche Gedanken. [...] Wo mein Name noch genannt wird, geschieht es immer nur in Verbindung mit dem 'Auswahlprinzip', auf das ich niemals Prioritätsanspruche gestellt habe. [...] Dabei erinnere ich mich, daß schon bei der Mathematiker-Tagung in Bad Elster mein Vortrag über Satz-Systeme durch eine Intrige der von Hahn und Gödel vertretenen Wiener Schule von der Diskussion ausgeschlossen wurde, und habe seitdem die Lust verloren, über Grundlagen vorzutragen. So geht es augenscheinlich jedem, der keine 'Schule' oder Klique hinter sich hat. Aber vielleicht kommt noch eine Zeit, wo auch meine Arbeiten wieder entdeckt und gelesen werden. ${ }^{18}$
\end{abstract}

Nie zamierzamy w tym miejscu rozwodzić się nad domniemanymi przyczynami tonu rezygnacji zawartego w powyższych słowach (zob. w tej sprawie np. cytowana praca Peckhausa). Różni autorzy (np. G.H. Moore, H.D. Ebbinghaus, J. Ferreirós,...) zwracali uwagę na niezwykle ciekawy fakt w historii logiki XX wieku: rozważania dotyczące logik infinitarnych prowadzone z początku w sposób nieusystematyzowany zostały w pewnym momencie (prawie) całkowicie zarzucone, a po dwóch dekadach podjęte na nowo, już w inny, z metodologicznego punktu widzenia, sposób. Rzecz jest interesująca nie tylko dla logików, matematyków i filozofów, ale także chyba dla socjologów nauki. Logika i metalogika rozwijają się w XX wieku jednocześnie; jednak w pewnych okresach to jedna, to znów druga rozwija się szybciej. Owo „nienadążanie” staje się, być może, inspiracją dla rozwoju.

Szkicowe, nie do końca formalne propozycje Zermela dotyczące logiki infinitarnej wyprzedzały chyba stan badań w ówczesnej logice. Poniżej staramy się krótko wskazać na okoliczności towarzyszące tym propozycjom i zwięźle sprawozdać wybrane ważne fakty z późniejszego etapu rozwoju logik. Poniższe uwagi wykorzystują informacje i refleksje zawarte m.in. w: [Moore 1995], [Bell 2004], [Keisler, Knight 2004], [Barwise, Feferman (Eds.) 1985].

Gdy mówimy o logice, że jest infinitarna, to możemy mieć na myśli np. to, że:

- rozważany język dopuszcza formuły nieskończenie długie;

- dopuszcza się nieskończenie długie dowody;

- stosuje się niefinitarne reguły wnioskowania (np. $\omega$-regułę). ${ }^{19}$

Cechy dotyczą składni - budowy wyrażeń rozpatrywanych w danym systemie logiki oraz operacji (tu: inferencji) dokonywanych na takich wyrażeniach.

Na marginesie zauważmy, że nieskończoność zbioru wyrażeń danego języka jest cechą niezbędną dowolnego systemu logiki — nie ma żadnych ograniczeń na długość rozważanych formuł. Podobnie jak w lingwistyce, (potencjalna) nieskończoność zbioru wszystkich wyrażeń poprawnych traktowana jest jako universale semiotyczne. Zbiór symboli prostych (alfabet, słownik) może być skończony; występowanie choćby jednej rekursywnej reguły tworzenia wyrażeń oznacza już, że wszystkich wyrażeń jest nieskończenie wiele. Systemy semiotyczne bez cechy otwartości są ograniczone do ściśle wyznaczonego odniesienia przedmiotowego.

Nieco od rzeczy dodajmy jeszcze, że argumentacja za językami finitarnymi (o wyrażeniach skończonych, lecz dowolnej długości) jako dobrze przystającymi do naszych (skończonych rzekomo) możliwości intelektualnych wykorzystuje oczywiste założenie idealizacyjne. Pomijamy bowiem w takiej argumentacji różne aspekty pragmatyczne związane z konstruowaniem systemów logicznych.

Także od rzeczy zauważmy, że asymetria między składnią a semantyką finitarnych systemów logicznych jest wyraźna: oto o dowolnych (dowolnej mocy) strukturach „mówić” mamy w językach o z góry zadanych nie tylko środkach nazywania, ale także wyrażania. Z drugiej strony, nie widać innej możliwości rozszerzania rozumienia pojęcia (abstrakcyjnego) języka, niż traktowanie takich uogólnionych języków jako tworów reprezentowanych teoriomnogościowo.

\footnotetext{
${ }^{18}$ Zob. [Peckhaus 1990: 20].

${ }^{19}$ Czy logikę zaczynamy uważać za infinitarną także wtedy, gdy alfabet używanych symboli jest nieprzeliczalny, choć wyrażenia i reguły inferencji są finitarne?
} 
$\mathrm{Na}$ koniec tych uwag wstępnych zaznaczmy, że w dalszym ciągu zajmować się będziemy infinitarnymi aspektami języków logiki, poza dyskusją zostawiając wszelakiego typu notacje języka matematyki, pretendujące do statusu tworów syntaktycznie nieskończonych.

\subsection{Logika infinitarna: prehistoria}

Wedle G. H. Moore'a (zob. [Moore 1995: 109]) pierwsze użycia formuł nieskończonych w logice znajdujemy u George'a Boole'a w Mathematical Analysis of Logic (z 1847 roku), gdzie dowolne funkcje boolowskie rozwijane są w formalne szeregi MacLaurina. Także w Laws of Thought (z 1854 roku) Boole stosuje takie konstrukcje.

W 1885 roku formuł nieskończonych używa Peirce, wprowadzając swoją symbolikę dla kwantyfikatorów:

Here ... we may use $\sum$ for some, suggesting a sum, and $\prod$ for all, suggesting a product. Thus $\sum_{i} x_{i}$ means that $x$ is true of some of the individuals denoted by $i$ or $\sum_{i} x_{i}=x_{i}+x_{j}+x_{k}+$ etc. In the same way, $\prod_{i} x_{i}$ means that $x$ is true of all these individuals, or $\prod_{i}^{i} x_{i}=x_{i} x_{j} x_{k}$ etc.... $\sum_{i} x_{i}$ and $\prod_{i} x_{i}$ are only similar to a sum and product; they are not strictly of that nature, because the individuals of the universe may be innumerable.

[Peirce 1885: 194-195]; cytat za [Moore 1995: 110].

Schröder w swoim monumentalnym dziele Vorlesungen über die Algebra der Logik z 1885 roku również czyni użytek z nieskończenie długich formuł. Pewne trudności interpretacyjne stwarza, jak wiadomo, stosowana przez niego (niejednoznaczna) notacja. Niepublikowane za życia notatki Schrödera zostały później opracowane przez E. Müllera i wydane w 1910 roku jako Abriss der Algebra der Logik — tam również znajdujemy stwierdzenia o równoważności formuł z kwantyfikatorami z nieskończonymi koniunkcjami i alternatywami.

W tradycji ,algebraicznej” (nawiązującej do Peirce'a i Schrödera) piszą Leopold Löwenheim (zob. [Löwenheim 1915]) oraz Thoralf Skolem (zob. [Skolem 1919, 1920, 1922]). W swoim słynnym artykule z 1915 roku (zawierającym pierwsze wyniki metalogiczne) Löwenheim używa nie tylko nieskończonych koniunkcji i alternatyw, lecz również nieskończonych prefiksów kwantyfikatorowych. Nadto, można twierdzić, że posługiwał się infinitarną regułą wnioskowania, uznając, że gdy nieskończona liczba zdań jest prawdziwa, to prawdziwa jest również formuła nieskończona, będąca ich koniunkcja. Protosystem, w którym pracował Löwenheim wykorzystywał więc środki typowe dla infinitarnej logiki drugiego rzędu. W uogólnieniach i rektyfikacjach wyników Löwenheima podanych przez Skolema, ten ostatni czynił istotny użytek z logiki infinitarnej. Ostatecznie, aparat pojęciowy, którego używał (w [Skolem 1919] i w [Skolem 1920]) traktujemy dziś jako systemy oznaczane przez $L_{\omega_{1} \omega}$ oraz $L_{\omega_{1} \omega_{1}}$ - mianowicie Skolem dopuszczał również rozważanie formuł (w swoich postaciach normalnych) z nieskończonymi prefiksami kwantyfikatorowymi (początek takiego prefiksu stanowiło skończenie wiele kwantyfikatorów generalnych, po których mogło następować przeliczalnie wiele kwantyfikatorów egzystencjalnych). Definitywne zerwanie Skolema z logiką infinitarną to jego artykuł [Skolem 1922], zawierający m.in. krytyczne uwagi o aksjomatycznym systemie teorii mnogości Zermela oraz (po raz pierwszy!) sformułowanie aksjomatyki dla teorii mnogości wyłącznie w języku pierwszego rzędu.

G. H. Moore do prehistorii logiki infinitarnej (w nurcie algebraicznym) zalicza też pewne prace Hilberta i Lewisa. Hilbert początkowo (w 1905 roku) korzystał z wyrażeń infinitarnych, następnie, do późnych lat dwudziestych XX wieku eliminował tego rodzaju wyrażenia, jednak w 1931 roku wprowadził infinitarną regułę wnioskowania.

Lewis, reprezentując formuły skwantyfikowane jako równoważne nieskończonym koniunkcjom i alternatywom miał nadto świadomość, że jego nieskończone wyrażenia mogą zawierać nieprzeliczalnie wiele symboli (zob. [Lewis 1918]). 
Również w drugiej z żywotnych w pierwszej połowie XX wieku tradycji, tj. tradycji wiązanej z Principia Mathematica, znajdujemy — u Russella, Wittgensteina oraz Ramseya — rozważania używające formuł nieskończonych.

Obok krótkiej wzmianki o poglądach Zermela (z lat 1930-1935) G. H. Moore zwraca uwagę na powstałe około roku 1940 pomysły Carnapa, Nowikowa, Boczwara dotyczące infinitarnych systemów logiki. Carnap rozważał m.in. infinitarne reguły wnioskowania. Na marginesie zauważmy, że wzmiankę o infinitarnej regule wnioskowania (dziś nazywanej $\omega$-regułą) znajdujemy też w 1928 roku w podręczniku Kazimierza Ajdukiewicza Gtówne zasady metodologji nauk i logiki formalnej (skrypt autoryzowany, zredagowany przez Mojżesza Presburgera); zob. [Ajdukiewicz 1928]. O propozycjach Carnapa wzmiankuje Abraham Robinson w swoich badaniach z początku lat pięćdziesiątych XX wieku (zob. [Robinson 1951]). Nowikow rozważał, całkiem niezależnie od logików zachodnich, systemy z przeliczalnymi koniunkcjami oraz alternatywami w 1939 roku. Własnościami metalogicznymi tych rachunków zajmował się Boczwar. Prace Nowikowa i Boczwara nie zyskały akceptacji logików w latach czterdziestych (m.in. za sprawą negatywnych o nich opinii Churcha), zostały natomiast ,zrehabilitowane" w latach osiemdziesiątych przez Barwise'a, który metodami semantycznymi wykazał ich poprawność.

W pracach dotyczących definiowalnych typów porządkowych Kuratowski używał kwantyfikatorów postaci istnieje liczba naturalna $n$ taka, ze $\varphi_{n}(x)$ (gdzie $\varphi$ jest formułą języka predykatów pierwszego rzędu), stwierdzając, że wyrażenie takie jest semantycznie równoważne nieskończonej (przeliczalnej) alternatywie (zob. [Kuratowski 1937]). Tarski zmodyfikował wtedy nieco to podejście Kuratowskiego, eliminując nieskończone alternatywy poprzez wprowadzenie stosownego predykatu od dwóch zmiennych: $P(x, n)$ równoważnego formule $\varphi_{n}(x)$.

W nieco podobnej jak Zermelo izolacji rozważał też projekty logiki infinitarnej Helmer (zob. [Helmer 1938]). Brał pod uwagę formuły nieskończenie długie (dobrze uporządkowane ciągi symboli typu porządkowego mniejszego niż $\omega^{2}$ ), nieskończenie długie „wyrażenia numeryczne” (kodowania liczb rzeczywistych); stosował zasadę indukcji i regułę odpowiadająca aksjomatowi ciągłości Dedekinda; formułował też analogon twierdzenia Gödla o niezupełności, przy czym rozważał podwójną niezupełność systemu: dedukcyjną i definicyjną.

Na wstrzymanie badań logik infinitarnych (ok. roku 1940) decydujący wpływ miały, jak się powszechnie uważa, poglądy Gödla, propagującego standard (finitarnej) logiki pierwszego rzędu.

\subsection{Logika infinitarna: historia}

O systematycznym rozwijaniu logik infinitarnych mówić można od połowy lat pięćdziesiątych XX wieku (do tego czasu nie było chyba świadomości tradycji takich badań).

Stanowisko metodologiczne Tarskiego, jeśli chodzi o wykorzystywanie logik infinitarnych ulegało zmianom. W latach trzydziestych XX wieku, gdy formułował (klasyczne, akceptowane do dziś) matematyczne podstawy semantyki, odrzucał możliwość wykorzystywania nieskończonych formuł. Dwadzieścia lat później, między innymi właśnie z jego inicjatywy, rozpoczęły się intensywne badania logik infinitarnych. ${ }^{20}$ Poszukiwano systemów logicznych mocniejszych od logiki pierwszego rzędu (której możliwości wyrażania pewnych ważnych, będących w powszechnym użyciu pojęć matematycznych są ograniczone), ale jednocześnie takich, które miałyby pożądane własności metalogiczne. Warto może zauważyć, że badania logik infinitarnych nie ograniczały się do rozważań dotyczących jedynie samych tych logik — dla przykładu, zostały one wykorzystane (1960) dla rozstrzygnięcia długo nierozwiązanego problemu, czy pierwsza liczba mocno nieosiagalna jest mierzalna.

Rozpoczęte w połowie lat pięćdziesiątych XX wieku intensywne badania logik infinitarnych miały inspiracje przede wszystkim algebraiczne. W 1951 roku Robinson używa nieskończonych koniunkcji oraz alternatyw w pracach algebraicznych (np. aksjomat Archimedesa daje się przedstawić jako

\footnotetext{
${ }^{20}$ Jak pisze G.H. Moore, w 1957 roku Tarski cytuje pracę [Jordan 1949], zaś w 1958 roku pracę [Krasner 1938], jako poprzedzające jego własne badania logik infinitarnych z lat pięćdziesiątych — [Moore 1995:109].
} 
nieskończona alternatywa).

Jak wiadomo, Stone w 1936 roku przedstawił twierdzenie o reprezentacji dla algebr Boole'a (w jednej z wersji: każda algebra Boole'a jest homomorficznym obrazem jakiegoś ciała zbiorów). W 1947 roku Loomis wzmocnił ten wynik, pokazując, iż każda $\sigma$-zupełna algebra Boole'a jest $\sigma$-homomorficznym obrazem pewnego $\sigma$-ciała zbiorów. W latach pięćdziesiątych Tarski, Chang oraz Scott uzyskali dalsze wyniki o reprezentacji algebr Boole'a. W tymże czasie Tarski zainspirował Henkina do prac nad uogólnieniami jego wcześniejszych wyników dotyczących algebr cylindrycznych. Jednym z głównych wyników tej teorii Tarskiego było twierdzenie o reprezentacji lokalnie skończonych, nieskończenie wymiarowych algebr cylindrycznych. Algebry takie, jak wiadomo, tworzą algebraiczne odpowiedniki dla logiki pierwszego rzędu. Henkin, z inspiracji Tarskiego, zajął się uogólnieniem twierdzeń o reprezentacji $\omega$-wymiarowych algebr cylindrycznych i szukania odpowiadających im rozszerzeń logiki pierwszego rzędu. Wykorzystywał m.in. symbole relacyjne o nieskończonej liczbie argumentów. Uzyskał też pewne wyniki metalogiczne dotyczące tych logik infinitarnych. Według Moore'a ([Moore 1995: 107] oraz [Moore 1995: 121]), granicę między prehistorią a historią badań logik infinitarnych wyznaczają prace [Henkin 1955] i [Robinson 1957].

Systematyczną prezentacją systemu logiki z nieskończenie długimi formułami zajmowała się Carol Karp, pisząc swoją rozprawę doktorską u Henkina.

Pod koniec lat pięćdziesiątych Tarski i Scott badali rachunki zdaniowe z koniunkcjami i alternatywami o długości mniejszej niż jakaś (dowolna) nieskończona regularna liczba kardynalna. W szczególności, uzyskali wyniki dotyczące pełności takich rachunków (np. [Scott, Tarski 1957, 1958]). Tarski rozważał też w tym czasie systemy logiki w dzisiejszej symbolice oznaczane jako $L_{\omega_{1} \omega_{1}}$.

Jedne z pierwszych ujęć monograficznych logik infinitarnych to klasyczne już książki: [Karp 1964] (Languages with expressions of infinite length) oraz [Dickmann 1975] (Large infinitary languages). Wielce istotna była też monografia [Keisler 1971] (Model theory for infinitary logic). Z ważnych prac nieco późniejszych wspomnijmy monumentalną monografię pod redakcją Barwise'a i Fefermana: Model Theoretic Logics (tj. [Barwise, Feferman (Eds.) 1985]).

\subsection{Logiki infinitarne - kilka uwag o współczesności}

Na zakończenie, podamy pewne informacje o wybranych ustaleniach dotyczących logik infinitarnych. Są to fakty powszechnie znane w środowisku logicznym; ich przywołanie tutaj ma służyć jedynie konfrontacji celów deklarowanych w projekcie Zermela z efektami uzyskanymi na drodze, którą wybrała współczesna logika matematyczna.

\subsubsection{Ile mocy (wyrażeniowej) potrzebuje logika?}

Jakie są główne przyczyny (natury metodologicznej!), dla których klasyczna logika pierwszego rzędu powszechnie uważana jest za standard logiki współczesnej, za the logic? To przede wszystkim fakt, że logika ta ma pewne pożądane (przez logików) własności metalogiczne, że jest produktem spełniającym standardy odpowiadające pewnym (wybranym z różnych powodów) ideałom metodologicznym. FOL jest petna — zbiór jej tez pokrywa się ze zbiorem jej praw (tautologii), ${ }^{21}$ a więc dostarcza ufności w adekwatność czynionych w jej aparaturze inferencyjnej uzasadnień (dowodów, rozumianych jako obiekty finitarne, złożone z formuł, będących również obiektami finitarnymi i to obiektami, które rozważamy jedynie ze względu na ich formę, bez odwoływania się do ich znaczenia). FOL spełnia twierdzenie o zwartości, na mocy którego dowolny zbiór formuł jest sprzeczny dokładnie wtedy, gdy co najmniej jeden jego skończony podzbiór jest sprzeczny (a więc, mówiąc koślawą metaforą, sprzeczność jakiegoś zbioru formuł nie może być całkiem arbitralnie „,rozproszona” - można ją ,zlokalizować" w jakimś skończonym podzbiorze tego zbioru ${ }^{22}$ ). FOL spełnia twierdzenie o neutralności

\footnotetext{
${ }^{21}$ Jest także pełna w sensie silnym — syntaktyczna wyprowadzalność pokrywa się z (semantycznym) wynikaniem logicznym. Może nietaktowne jest przypomnienie, że zbiór tez FOL jest niesprzeczny, ale wymieńmy także tę własność.

${ }^{22} \mathrm{~A}$ więc w jednej formule, będącej koniunkcją formuł tego skończonego podzbioru.
} 
symboli nie bedacych stałymi logicznymi - żaden symbol pozalogiczny nie jest wyróżniony (metaforycznie: FOL abstrahuje od jakości). FOL spełnia twierdzenia Skolema-Löwenheima-Tarskiego — w uproszczeniu, gdy jakiś zbiór formuł ma co najmniej jeden model nieskończony, to ma modele wszystkich mocy nieskończonych, a więc żaden model nie jest wyróżniony, jeśli chodzi o moc uniwersum (metaforycznie: FOL abstrahuje od ilości). Petnośćc oraz zwartość to własności uważane za konstytutywne dla procesów dedukcji. Pozostałe z wymienionych własności wiążą się z uniwersalnościq aplikacyjną logiki, cechą programowo w niej pożądaną.

Fakt, że FOL ma w wymienionym wyżej sensie walor systemu dedukcyjnego o uniwersalnej stosowalności podnoszony jest przez zwolenników Tezy Pierwszego Rzędu, głoszącej, iż to właśnie klasyczna logika pierwszego rzędu jest prawdziwa, właściwa, itp. logiką. Wielce interesująca dyskusję tej problematyki znaleźć można np. w Woleński 2004.

Założenia dotyczące składni i maszynerii inferencyjnej FOL (finitarność formuł i dowodów, rekurencyjność aksjomatyki, itd.) mają dobrze znane konsekwencje dla teorii formułowanych w językach pierwszego rzędu. Przede wszystkim, nie są w nich w ogólności możliwe kategoryczne charakterystyki odniesień przedmiotowych, a więc to, co zwykle interesuje matematyków opisujących badane przez siebie struktury z doktadnościq do izomorfizmu. Dalej, środkami dostępnymi w danej, wystarczająco bogatej (jak zwykło się mawiać) teorii pierwszego rzędu nie można ustalić pewnych faktów metalogicznych teorii tej dotyczących - mamy tu oczywiście na myśli twierdzenia Gödla o niezupełności oraz o niedowodliwości niesprzeczności (np. arytmetyki Peana), twierdzenie Churcha (o nierozstrzygalności klasycznego rachunku predykatów), twierdzenie Tarskiego (o niedefiniowalności predykatu prawdziwości formuł danej teorii w niej samej), itd. Są to po prostu „twarde” fakty; nieroztropne (jeśli nie wręcz dziecinne) byłoby rozdzieranie z tego powodu szat. Wspomniane wyniki metalogiczne uświadomiły, że pewne ideały metodologiczne, pożądane każdy z osobna, nie są współmożliwe, pewnych ich kombinacji nie możemy uzyskać.

Rzecz jasna, jeszcze zanim logika pierwszego rzędu zaczynała krzepnać jako standard było dla wszystkich oczywiste, że środki wyrażania jej języka mają ograniczenia nie pozwalające np. na „mówienie" o wielu ważnych pojęciach matematycznych, a więc iż formalnie traktowane inferencje w FOL nie w pełni przystają do codziennej praktyki badawczej matematyka. Do najczęściej przywoływanych w tym kontekście przykładów należą, m.in.: niemożność scharakteryzowania pojęcia nieskończoności (i, w konsekwencji, także skończoności) formuła języka pierwszego rzędu, podobnie dla pojęcia dobrego porządku, konieczność używania nieskończonych alternatyw (bądź koniunkcji) w aksjomatycznych opisach charakteryzujących pewne struktury algebraiczne (np. aksjomat Archimedesa), itd.

Wzbogacać możliwości wyrażania pojęć w danym języku (i bazującej na nim logice) można na różne sposoby. Jednym z nich jest rozszerzenie listy stałych logicznych. Innym — dopuszczenie określonych konstrukcji syntaktycznych, uznawanych w języku wyjściowym za nieuprawnione (np. dopuszczenie nieskończenie długich formuł). Jeszcze innym — rozszerzenie aparatury inferencyjnej wyjściowej logiki (np. akceptowanie nieskończenie długich dowodów, stosowanie infinitarnych reguł wnioskowania). Oczywiście taka radosna kreatywność podlegać musi pewnym rygorom metodologicznym. Urodzone (nie poronione) systemy logiczne spełniać powinny jakieś rozsądne warunki, będące uogólnionymi analogonami znanych własności metalogicznych. Dla przykładu, kodowanie tworów syntaktycznych liczbami naturalnymi zastępować można kodowaniami przez rozumnie dobrane obiekty, tak aby uogólniona teoria rekursji była koherentna z uogólnieniami teoriomodelowymi oraz teoriodowodowymi.

Zauważmy na marginesie, że w historii logiki spotykamy nie tylko przypadki rozszerzania środków wyrażania używanych języków, lecz miewamy również do czynienia z sytuacjami odwrotnymi — tak rzeczy się miały np. z relacją $\in$ należenia elementu do zbioru, wypędzonej z czyśćca Principia Mathematica do raju pocantorowskiej aksjomatycznej teorii mnogości. Rozstrzyganie sporów na temat tego, co jest stałą logiczną (pomyślmy np. o statusie predykatu identyczności, boskim rzekomo podarunku liczb naturalnych, relacjach mereologicznych, zdaniotwórczych operatorach modalnych o 
argumentach zdaniowych, ... ) może brać pod uwagę argumenty metodologiczne inspirowane matematycznie (zob. np. znaną, wzorowaną na programie erlangejskim Kleina propozycję Tarskiego: [Lindenbaum, Tarski 1936], [Tarski 1986]), ale także chyba argumenty natury pragmatycznej, związane np. z uświadomieniem sobie roli, którą w inferencjach pełnią pewne, dotąd nie brane pod rozwagę, czynniki (por. np. renesans zainteresowania logikami modalnymi, związany zarówno z badaniami wnioskowań uzależnionych od kontekstu, jak i zastosowaniami w informatyce). W polskiej literaturze przedmiotu warta polecenia jest antologia Filozofia logiki pod redakcją Jana Woleńskiego (zob. [Woleński 1997]).

Rozszerzanie środków wyrażania systemu logiki klasycznej przez wprowadzenie nowych stałych logicznych znajduje wyraz np. w rozważaniu uogólnionych kwantyfikatorów — zob. [Mostowski 1957]. Początkowo badano kwantyfikatory numeryczne (np. $Q_{\alpha}$ jest kwantyfikatorem o zamierzonej interpretacji istnieje co najmniej $\boldsymbol{\aleph}_{\alpha}$ obiektów), potem rozważano też inne typy prefiksów kwantyfikatorowych (np. kwantyfikatory rozgałęzione — zob. [Henkin 1959]). Prace Lindströma z lat sześćdziesiątych oraz Barwise'a z lat siedemdziesiątych XX wieku stworzyły całą nową dziedzinę badań (abstract logics, soft model theory), zob. np. [Lindström 1966, 1969], [Barwise 1974]. Obszerne informacje na ten temat znaleźć można np. w: [Barwise, Feferman (Eds.) 1985], [Shapiro (Ed.) 1996], [Westerståhl 1989], [Krynicki, Mostowski, Szczerba (Eds.) 1995]. ${ }^{23}$

\subsubsection{Metalogika dla logik infinitarnych}

Interpretatorzy tekstów Zermela różnią się w poglądach, jakiego typu (współczesna) logika infinitarna jest najbliższa jego oryginalnym, półformalnym propozycjom. Uważa się np., że można rekonstruować ją jako:

- logikę $L_{\infty \infty}$;

- logikę $L_{\kappa \kappa}$, gdzie $\kappa$ jest liczbą kardynalną mocno nieosiągalną;

- logikę $L_{\infty \omega}$;

- logikę drugiego rzędu. ${ }^{24}$

Logiki te różnią się, rzecz jasna, mocą wyrażania. Wspominaliśmy już, że pewne pojęcia są niewyrażalne w $L_{\omega \omega}$, czyli w klasycznej logice pierwszego rzędu. Są one natomiast wyrażalne w $L_{\alpha \beta}$, dla stosownie dobranych $\alpha$ oraz $\beta$. Przypomnijmy parę przykładów:

- w $L_{\omega_{1} \omega}$ scharakteryzować można model standardowy arytmetyki Peana;

- w $L_{\omega_{1} \omega}$ scharakteryzować można klasę wszystkich zbiorów skończonych;

- teoria uporządkowanych ciał archimedesowych jest $\mathrm{w} L_{\omega_{1} \omega}$ skończenie aksjomatyzowalna;

- predykat prawdziwości formuł języka o przeliczalnej liczbie symboli jest definiowalny w $L_{\omega_{1} \omega}$;

- pojęcie dobrego porządku nie jest definiowalne w $L_{\omega_{1} \omega}$, jest natomiast definiowalne (pojedynczą formułą) w $L_{\omega_{1} \omega_{1}}$.

Jak wiadomo, logiki infinitarne, w których dopuszcza się nieskończone prefiksy kwantyfikatorowe są bliższe logice drugiego rzędu, z wszelkimi tego faktu konsekwencjami, a więc, w szczególności, brakiem pełności. Dla $L_{\omega_{1} \omega_{1}}$ zachodzi twierdzenie Scotta o niedefiniowalności predykatu

\footnotetext{
${ }^{23}$ Jest naszą nieśmiałą, nieskromną ambicją poświęcenie więcej miejsca tej problematyce w przygotowywanej rozprawie.

${ }^{24}$ Zakładamy, że ewentualnemu czytelnikowi tego tekstu są znane stosowane tu oznaczenia oraz, w ogólności, elementarne wiadomości dotyczące składni i semantyki języków $L_{\alpha \beta}$ — zob. np. [Barwise, Feferman (Eds.) 1985].
} 
prawdziwości w tymże języku; definiowalność jest tu rozumiana w odpowiedni sposób, z wykorzystaniem kodowań w klasie wszystkich zbiorów dziedzicznie przeliczalnych. Wśród logik infinitarnych o skończonych prefiksach kwantyfikatorowych szczególne miejsce zajmuje $L_{\omega_{1} \omega}$. Zachodzi w niej twierdzenie o pełności, gdy na obecną w niej infinitarną regułę wnioskowania pozwalającą wywnioskować koniunkcję $\wedge \Phi$ ze zbioru przesłanek $\Phi$ narzucimy warunek, aby $\Phi$ był przeliczalny. Warunek ten jest istotny: istnieje nieprzeliczalny zbiór zdań języka $L_{\omega_{1} \omega}$, który nie ma modelu, a którego każdy przeliczalny podzbiór ma model. Przykład ten pokazuje jednocześnie, że ani $\mathrm{w} L_{\omega_{1} \omega}$, ani w żadnej z $\operatorname{logik} L_{\alpha \beta}$, gdzie $\alpha \geqslant \omega_{1}$, nie zachodzi twierdzenie o zwartości. Rozważano jednak stosowne modyfikacje tego twierdzenia i wykazano, iż zachodzenie tych uogólnionych wersji twierdzenia o zwartości powiązane jest $\mathrm{z}$ istnieniem dużych liczb kardynalnych.

$\mathrm{W} L_{\omega_{1} \omega}$ dowolną przeliczalną strukturę z przeliczalną liczbą relacji można scharakteryzować z dokładnością do izomorfizmu, jak wiadomo ze słynnego twierdzenia Scotta o izomorfizmie. Własności semantyczne modeli dla logik $L_{\alpha \omega}$ i $L_{\infty \omega}$ (np. elementarną równoważność) można charakteryzować metodami algebraicznymi (twierdzenie Karp o częściowych izomorfizmach).

Oczywiście, nie jest celem tego streszczenia dokonywanie przeglądu najważniejszych ustaleń metalogicznych dla logik infinitarnych. Można się zastanawiać, jaka byłaby reakcja antyskolemity Zermela na wiadomość, że dolne twierdzenie Löwenheima-Skolema ma swój odpowiednik w $L_{\omega_{1} \omega}$ oraz właściwie we wszystkich logikach infinitarnych. Natomiast górne twierdzenie LöwenheimaSkolema-Tarskiego w swojej zwykłej formie nie zachodzi w tych logikach; dokonuje się jednak podobnych do niego ustaleń, wykorzystując tzw. liczby Hanfa.

\subsubsection{Zbiory dopuszczalne i uogólniona rekursja}

Formuły logiki pierwszego rzędu $L_{\omega \omega}$ kodować można liczbami naturalnymi lub, co na jedno wychodzi, zbiorami dziedzicznie skończonymi, tj. elementami zbioru $H(\omega)$. Z kolei, formuły logiki $L_{\omega_{1} \omega}$ kodować można elementami zbioru $H\left(\omega_{1}\right)$, tj. zbiorami dziedzicznie przeliczalnymi. Także dowody w $L_{\omega_{1} \omega}$ kodować można elementami $H\left(\omega_{1}\right)$.

Dowody w logice $L_{\omega_{1} \omega}$ mają długość przeliczalną. Można jednak podać przykład zbioru zdań $\Gamma$ oraz zdania $\sigma \mathrm{z}$ tego języka takich, że $\Gamma \models \sigma$, ale nie istnieje dowód $\sigma \mathrm{z} \Gamma \mathrm{w} L_{\omega_{1} \omega}{ }^{25}$

Zbiór $H\left(\omega_{1}\right)$ jest domknięty na tworzenie przeliczalnych podzbiorów oraz ciągów. Jednak fakt wspomniany w poprzednim akapicie wskazuje iż, mówiąc w uproszczeniu, $H\left(\omega_{1}\right)$ nie jest domknięty ze względu na operację odpowiadającą kodowaniu dowodów z dowolnych $\Sigma_{1}$ na $H\left(\omega_{1}\right)$ zbiorów formul. ${ }^{26}$ Naturalne jest w tej sytuacji poszukiwanie takich zbiorów $A$ zastępujących $H\left(\omega_{1}\right)$, które byłyby domknięte na operacje odpowiadające kodowaniom dowodów w $A$ oraz rozważanie tylko takich formuł, które mają kody w $A$. Była to jedna z motywacji do rozpatrywania tzw. dopuszczalnych fragmentów $L_{A}$ logiki $L_{\omega_{1} \omega}$.

Barwise odkrył, że istnieją przeliczalne zbiory dopuszczalne (admissible sets) $A \subseteq H\left(\omega_{1}\right)$, które spełniają powyższe warunki. Są to więc takie uogólnienia zbiorów dziedzicznie skończonych, na których (jako na zbiorach kodów formuł) możliwe i sensowne jest uprawianie (uogólnionej) teorii rekursji oraz teorii dowodu. Udowodnił także swoje znamienite twierdzenie o zwartości: jeśli $A$ jest przeliczalnym zbiorem dopuszczalnym, to każdy zbiór formuł języka $L_{A}$ będący $\Sigma_{1}$ na $A$, którego każdy podzbiór (będący jednocześnie elementem $A$ ) ma model, sam również ma model. Twierdzenie Barwise'a ma mnogie zastosowania, m.in. pozwala np. udowodnić, że każdy przeliczalny przechodni model dla ZFC ma właściwe rozszerzenie końcowe. Prace Barwise'a to swego rodzaju unifikacja rozważań w teorii modeli, teorii rekursji oraz teorii mnogości.

Szczególnie przydatna dla badań zbiorów dopuszczalnych okazała się wersja teorii mnogości KP zaproponowana przez Kripke'go i Platka w połowie lat sześćdziesiątych XX wieku. Jest ona teorią elementarną (ze stałą pozalogiczną $\in$ ), będącą pewnym osłabieniem teorii mnogości Zermelo-

\footnotetext{
${ }^{25}$ Zbiór $\Gamma$ można dobrać w ten sposób, aby był on $\Sigma_{1}$ na $H\left(\omega_{1}\right)$; zob. np. [Bell 2004].

${ }^{26}$ Zob. np. [Bell 2004].
} 
Fraenkla. Nie ma w niej aksjomatu zbioru potęgowego, a szczególną rolę pełnią schematy aksjomatów $\Delta_{0}$-separation oraz $\Delta_{0}$-collection (odpowiedniki schematów aksjomatów wyróżniania i zastępowania), w których występują formuły klasy $\Delta_{0}$. Zbiory przechodnie $A$ takie, że $(A, \in)$ jest modelem KP nazywane są zbiorami dopuszczalnymi (admissible sets). Rozważa się także teorię KPU, czyli teorię $\mathrm{KP} \mathrm{z}$ atomami.

Kompletny wykład teorii zbiorów dopuszczalnych znaleźć można np. w klasycznej monografii [Barwise 1975]. Przystępne i zwięzłe omówienie (współczesnego stanu) tej teorii znajdujemy np. w [Keisler, Knight 2004]. ${ }^{27}$

\section{Realizacja programu Zermela?}

Czy któryś z nurtów rozwoju logik infinitarnych uważać można za realizację projektu Zermela? W szczególności, czy np. teoria zbiorów dopuszczalnych ugruntowana na bazie aksjomatyki KPU Kripke-Platka teorii mnogości z atomami może być, w jakimś sensie uważana za (spełniający dzisiejsze standardy poprawności metodologicznej) odpowiednik półformalnych propozycji Zermela? A może bliższe ideom Zermela byłyby propozycje uważania (różnych systemów) logiki drugiego rzędu (lub systemów logik zajmujących miejsce pośrednie między logiką pierwszego a drugiego rzędu) jako logiki adekwatnej dla inferencji przeprowadzanych przez matematyków? Jak odpowiedziałby na tego typu pytania sam Zermelo? Podkreślał zawsze, iż jest matematykiem, stawiał refleksję logiczną chyba na drugim planie, a filozoficzną na całkiem odległym (i oba te typy refleksji chciałby zapewne podporządkować idei nadrzędnej: matematyka jest logika nieskończoności).

Pozwólmy sobie na zakończenie przywołać dwa cytaty związane, jak się wydaje, z próbami odpowiedzi na powyższe pytania:

The landscape of logic has changed in the past 30 years. Developments in classification theory and $o$-minimal structures have left infinitary logic with a much diminished place in model theory. As a result, Barwise's idea of using $H Y P_{\mathscr{M}}$ to study a structure $\mathcal{M}$ has remained on the back burner. Perhaps this attractive idea will be taken up again by some future logician. On the other hand, infinitary logic is of growing importance for computable structure theory, finite model theory, and certain parts of theoretical computer science.

[Keisler, Knight 2004: 33]

Considering Zermelo and his reactions to "Skolemism" — or, as one might say, FOL-mania — one can think of other deviant historical scenarios. Imagine a world in which the 20th century begins with some author who offers such a convincing solution to the paradoxes, that everybody agrees. (This might have been a clear presentation of the iterative conception of sets, which was somehow present in the practice of 19th-century mathematicians.) Imagine, further, that this solution makes set theory appear as a consistent mathematical theory that does not belong to logic. Within such a context, the strong interest in formal systems and proof theory, that was so characteristic of the 1920s and 1930s, might not have emerged. But, without this, the key reason for focusing on FOL would have disappeared from the scene. The main foundational theme of the era might have been, not consistency, but a semantic question - the codification of crucial mathematical notions such as that of natural number and real number, meaning the categorical characterization of such notions. Had this been the case, the recommendations of Hilbert and Church would have been heard and second-order logic would probably have taken the paradigmatic role that was played, in fact, by FOL.

\footnotetext{
${ }^{27}$ Być może przypuszczenie, że da się dokonywać porównań między oryginalnym projektem Zermela a logikami infinitarnymi bazującymi na KPU i zbiorach dopuszczalnych jest tylko urojeniem piszącego te słowa.
} 
Mathematical logic is what logic, through twenty-five centuries and a few transformations, has become today. As we have seen, these transformations were not merely questions of detail they involved fundamental changes in conception of the subject and delimitation of its scope.

[Ferreirós 2001: 480]. 


\section{Bliografia}

Ajdukiewicz, K. 1928. Główne zasady metodologji nauk i logiki formalnej. (Skrypt autoryzowany, zredagowany przez Mojżesza Presburgera.) Warszawa: Wydawnictwa Koła Matematyczno-Fizycznego Słuchaczów Uniwersytetu Warszawskiego.

Barwise, J. 1974. Axioms for abstract model theory. Annals of Mathematical Logic, vol. 7, 221-265.

Barwise, J. 1975. Admissible Sets and Structures. An Approach to Definability Theory. Berlin Heidelberg New York: Springer Verlag.

Barwise, J., Feferman, S. (Eds.) 1985. Model-Theoretic Logics. New York Berlin Heidelberg Tokyo: Springer Verlag.

Batóg, T. $2000^{2}$. Dwa paradygmaty matematyki. Studium z dziejów i filozofii matematyki. Poznań: Wydawnictwo Naukowe UAM.

Bell, J.L. 2004. Infinitary Logic. Stanford Encyclopedia of Philosophy.

Benacerraf, P., Wright, C. 1985. Skolem and the Skeptic. Proceedings of the Aristotelian Society, Supplementary Volume 59, 85-137. Reprinted in: [Shapiro 1996].

Bays, T. 2000. Reflections on Skolem's Paradox. PhD Thesis.

Buldt, B. 2002. Kompaktheit und Endlichkeit in der formalen Logik. In: B. Buldt u.a. (Hrsg.) Kurt Gödel. Wahrheit und Beweisbarkeit. Band 1: Dokumente und historische Analysen, Band 2: Kompendium zum Werk. Wien: öbv\&hpt VerlagsgmbH \& Co., 31-49.

van Dalen, D., Ebbinghaus, H.D. 2000. Zermelo and the Skolem Paradox. The Bulletin of Symbolic Logic Volume 6, Number 2 145-161.

Dawson, J.W. 1985. Completing the Gödel-Zermelo Correspondence. Historia Mathematica 12, 66-70.

DeLong, H. 1970. A Profile of Mathematical Logic. Addison-Wesley Publishing Company.

Dickmann, M.A. 1975. Large Infinitary Languages. Amsterdam: North Holland.

Ebbinghaus, H.D. 2001. Zermelo in the Mirror of the Baer Correspondence 1930-1931. Submitted for Historia Mathematica.

Na stronie: http://hrz.upb.de/ apeck1/zermelo/id9.htm

Ebbinghaus, H.D. 2003. Zermelo: On boundary numbers and domains of sets, Part II?

Na stronie: http://hrz.upb.de/ apeck1/zermelo/id9.htm

Ebbinghaus, H.D. 2003a. Zermelo: Definiteness and the Universe of Definable Sets. History and Philosophy of Logic 24, 197-219.

Ferreirós, J. 2001. The road to modern logic — an interpretation. The Bulletin of Symbolic Logic Volume 7, Number 4, 441-484.

Fraenkel, A. $1923^{2}$. Einleitung in die Mengenlehre. Berlin.

Fraenkel, A., Bar Hillel, Y., Levy, A. 1973. Foundations of set theory. Amsterdam - London: North Holland Publishing Company.

George, A. 1985. Skolem and the Löwenheim-Skolem Theorem: A Case Study of the Philosophical Significance of Mathematical Results. History and Philosophy of Logic, 6, 75-89. Reprinted in: [Shapiro 1996].

Grattan-Guinness, I. 1979. In memoriam Kurt Gödel: his 1931 correspondence with Zermelo on his incompletability theorem. Historia Mathematica 6, 294-304.

Hallet, M. 1984. Cantorian set theory and limitation of size. Oxford: Clarendon Press.

van Heijenoort, J. (Ed.) 1967. From Frege to Gödel: A source book in mathematical logic, 1879-1931. Cambridge, Mass.

Helmer, O. 1938. Languages with expressions of infinite length. Erkenntnis 8, 138-141.

Henkin, L. 1955. The Representation Theorem for Cylindrical Algebras. In: Mathematical Interpretation of Formal Systems. North Holland, 85-97.

Henkin, L. 1959. Some remarks on infinitely long formulas. In: Infinitistic Methods. Proceedings of the Symposium on Foundations of Mathematics. Warsaw, 2-9 September 1959. Oxford London New York Paris: Pergamon Press; Warszawa: Państwowe Wydawnictwo Naukowe, 167-183.

Hilbert, D., Bernays, P. 1934 (I), 1939 (II). Grundlagen der Mathematik. Berlin.

Hunter, G. 1971. Metalogic. An Introduction to the Metatheory of Standard First Order Logic. Macmilan Press.

Hunter, G. 1982. Metalogika. Warszawa: PWN.

Jordan, P. 1949. Zur Axiomatik der Verknüpfungsbereiche. Abhand. Math. Sem. Hamburg. Univ 16, 54-70.

Kanamori, A. 1996. The mathematical development of set theory from Cantor to Cohen. The Bulletin of Symbolic Logic Volume 2, Number 1, 1-71.

Kanamori, A. 2004. Zermelo and set theory. The Bulletin of Symbolic Logic Volume 10, Number 4, 487-553.

Karp, C. 1964. Languages with Expressions of Infinite Length. Amsterdam: North Holland.

Keisler, H.J. 1971. Model Theory for Infinitary Logic. Amsterdam: North Holland.

Keisler, H.J., Knight, J.L. 2004. Barwise: infinitary logic and admissible sets. The Bulletin of Symbolic Logic Volume 10, Number 1, 4-36.

Klenk, V. 1976. Intended Models and the Löwenheim-Skolem Theorem. Journal of Philosophical Logic, 5, 475-489. Reprinted in: [Shapiro 1996].

Krasner, M. 1938. Une généralisation de la notion de corps. Journal de Mathématiques Pures et Appliquées 9, 367-385.

Kripke, S. 1964. Transfinite recursion on admissible ordinals, I, II (abstracts). Journal of Symbolic Logic 29, 161-162.

Krynicki, M., Mostowski, M., Szczerba, L. (Eds.) 1995. Quantifiers, logics, models and computation. Kluwer Academic Publishers.

Kuratowski, K. 1937. Les types d'ordre définissables et les ensembles boreliens. Fundamenta Mathematicae 29, 97-100.

Lewis, C.S. 1918. A Survey of Symbolic Logic. Berkeley: University of California.

Lindenbaum, A., Tarski, A. 1936. Über die Beschränkheit der Ausdruckmittel deduktiver Theorien. Ergebnisse eines mathematischen Kolloquiums 7, 1934-1935, 15-22.

Lindström, P. 1966. First order predicate logic with generalized quantifiers. Theoria, 32, 186-195. 
Lindström, P. 1969. On Extensions of Elementary Logic. Theoria, 35, 1-11.

Löwenheim, L. 1915. Über Möglichkeiten im Relativkalkül. Mathematische Annalen, 68, 169-207. Translated and reprinted in: [van Heijenoort 1967], 228-251.

McCarthy, Ch., Tennant, N. 1987. Skolem's Paradox and Constructivism. Journal of Philosophical Logic, 16, 165-202. Reprinted in: [Shapiro 1996].

Moore, A.W. 1985. Set Theory, Skolem's Paradox and the Tractatus. Analysis, 45, 13-20.

Moore, G.H. 1980. Beyond First-order Logic: The Historical Interplay between Mathematical Logic and Axiomatic Set Theory. History and Philosophy of Logic, 1, 95-137. Reprinted in: [Shapiro 1996].

Moore, G.H. 1982. Zermelo's axiom of choice. Its origins, development and influence. New York, Heidelberg, Berlin.

Moore, G.H. 1995. The prehistory of infinitary logic: 1885-1955. In: Maria Luisa Dalla Chiara, Kees Doets, Daniele Mundici, Johan van Benthem (Eds.) Structures and norms in science. Volume two of the Tenth International Congress of Logic, Methodology and Philosophy of Science, Florence, August 1995, Kluwer Academic Publishers, 105-123.

Moore, G.H. 2002. Die Kontroverse zwischen Gödel und Zermelo. In: B. Buldt u.a. (Hrsg.) Kurt Gödel. Wahrheit und Beweisbarkeit. Band 1: Dokumente und historische Analysen, Band 2: Kompendium zum Werk. Wien: öbv\&hpt VerlagsgmbH \& Co., 55-64.

Mostowski, A. 1948. Logika matematyczna. Warszawa-Wroclaw.

Mostowski, A. 1957. On a generalization of quantifiers. Fundamenta Mathematicae, 44, 12-36.

Murawski, R. 2001². Filozofia matematyki. Zarys dziejów. Warszawa: Wydawnictwo Naukowe PWN.

Murawski, R. 2002. Wspótczesna filozofia matematyki. Warszawa: Wydawnictwo Naukowe PWN.

Murawski, R. 2003³ . Filozofia matematyki. Antologia tekstów klasycznych. Poznań: Wydawnictwo Naukowe UAM.

Myhill, J. 1951. On the ontological significance of the Löwenheim-Skolem theorem. In: M. White (Ed.) Academic Freedom, Logic and Religion. The University of Pennsylvania Press, 57-70.

Myhill, J. 1952. The hypothesis that all classes are nameable. Proc. Nat. Acad. Sci. USA, 38, 979.

von Neumann, J. 1925. Eine Axiomatisierung der Mengenlehre. Journal für die reine und angewandte Mathematik, 154, 219-240. Translated and reprinted in: [van Heijenoort 1967].

Peckhaus, V. 1990. 'Ich habe mich wohl gehütet, alle Patronen auf einmal zu verschießen'. Ernst Zermelo in Göttingen. History and Philosophy of Logic 11, 19-58.

Peckhaus, V. 200?. Pro and Contra Hilbert: Zermelo's Set Theories. Na stronie: http://hrz.upb.de/ apeck1/zermelo/id9.htm

Peirce, C.S. 1885. On the algebra of logic: a contribution to the philosophy of notation. American Journal of Mathematics 7, 180-202.

Platek, R. 1966. Foundations of recursion theory. Doctoral Dissertation and Supplement. Stanford: Stanford University.

Putnam, H. 1980. Models and Reality. Journal of Symbolic Logic, 45, 464-482.

Quine, W.V.O. 1966. Ontological Reduction and the World of Numbers. In: W.V.O. Quine The Ways of Paradox and Other Essays. New York: Random House, 199-207.

Resnik, M. 1966. On Skolem's Paradox. Journal of Philosophy Volume 63 Number 15, 425-438.

Resnik, M. 1969. More on Skolem's Paradox. Noûs, 3, 185-196.

Robinson, A. 1951. On the Metamathematics of Algebra. Amsterdam: North Holland.

Robinson, A. 1957. Applications to Field Theory. Summaries of talks at the Summer Institute for Symbolic Logic in 1957 at Cornell University, 326-331.

Schröder, E. 1895. Vorlesungen über die Algebra der Logik. Vol. 3, Leipzig.

Schröder, E. 1910. Abriss der Algebra der Logik, 2, E. Müller (Ed.), Leipzig.

Scott, D., Tarski, A. 1957. The sentential calculus with infinitely long expressions. Summaries of talks at the Summer Institute for Symbolic Logic in 1957 at Cornell University, 83-89.

Scott, D., Tarski, A. 1958. The sentential calculus with infinitely long expressions. Colloquium Mathematicum 6, 166-170.

Shapiro, S. (Ed.) 1996. The limits of logic: higher-order logic and the Löwenheim-Skolem theorem. Aldershot: Dartmouth Publishing Company.

Skolem, T. 1919. Untersuchungen über die Axiome des Klassenkalkuls und über Produktations- und Summationsprobleme, welche gewisse Klassen von Aussagen betreffen. Videnskapsselskapets skrifter, I. Matematisk-naturvedenskabelig klasse, no 3.

Skolem, T. 1920. Logisch-kombinatorische Untersuchungen über die Erfüllbarkeit oder Beweisbarkeit mathematischer Sätze nebst einem Theoreme über dichte Mengen. Videnskappselskapets skrifter, I. Matematisk-naturvedenskabelig klasse, no 4. Translated and reprinted in: [van Heijenoort 1967], 252-263.

Skolem, T. 1922. Einige Bemerkungen zur axiomatischen Begründung der Mengenlehre. Matematikerkongressen $i$ Helsingfors den 4-7 Juni 1922, Den femte skandinaviska matematikerkongressen, Redogörelse, (Akademiska Bokhandeln, Helsinki, 1923). Translated and reprinted in: [van Heijenoort 1967], 290-301.

Skolem, T. 1930. Einige Bemerkungen zu der Abhandlung von E. Zermelo "Über die Definitheit in der Axiomatik". Fundamenta Mathematicae 15, 337-341.

Suszko, R. 1951. Canonic axiomatic systems. Studia Philosophica, IV, 301-330.

Tarski, A. 1933. Pojecie prawdy w jezykach nauk dedukcyjnych. Towarzystwo Naukowe Warszawskie, Warszawa.

Tarski, A. 1934. Z badań metodologicznych nad definiowalnością terminów. Przegląd Filozoficzny 37, 438-460.

Tarski, A. 1986. What are logical notions? History and Philosophy of Logic, 7, 143-154.

Taylor, R.G. 1993. Zermelo, Reductionism, and the Philosophy of Mathematics. Notre Dame Journal of Formal Logic Volume 34, Number 4, 539-563.

Taylor, R.G. 2002. Zermelo's Cantorian theory of systems of infinitely long propositions. The Bulletin of Symbolic Logic Volume 8, Number 4, 478-515.

Thomas, W. 1971. On behalf of the Skolemite. Analysis 31, 177-186.

Thomas, W. 1968. Platonism and the Skolem Paradox. Analysis, 28, 193-196. 
Wang, H. 1955. On denumerable bases of formal systems. In: Mathematical interpretation of formal systems. Amsterdam: North Holland Publishing Company.

Wang, H. 1962. A survey of mathematical logic. Peking: Science Press, Amsterdam: North Holland Publishing Company.

Westerståhl, D. 1989. Quantifiers in formal and natural languages. In: D. Gabbay, F. Guenthner (Eds.) Handbook of Philosophical Logic, vol. IV, D. Reidel Publishing Company, 1-131.

Whitehead, A.N., Russell, B. 1910-1913. Principia Mathematica. Cambridge.

Woleński, J. (Ed.) 1997. Filozofia logiki. Warszawa: Wydawnictwo Spacja — Fundacja Aletheia.

Woleński, J. 2004. First-Order Logic: (Philosophical) Pro and Contra. In: V. Hendricks, F. Neuhaus, S.A. Pedersen, U. Scheffer, H. Wansing (Eds.) First-Order Logic Revisited. Berlin: Logos, 369-398.

Zermelo, E. 1902. Über die Addition transfiniter Cardinalzahlen. Nachrichten von der Königl. Gesellschaft der Wissenschaften zu Göttingen. Mathematisch-physikalische Klasse aus dem Jahre 1901, 34-38.

Zermelo, E. 1904. Beweis daß jede Menge wohlgeordnet werden kann. Mathematische Annalen 59, 514-516.

Zermelo, E. 1908. Untersuchungen über die Grundlagen der Mengenlehre I. Mathematische Annalen 65, 261-281.

Zermelo, E. 1908a. Neuer Beweis für die Möglichkeit einer Wohlordnung. Mathematische Annalen 65, 107-128.

Zermelo, E. 1909. Sur les ensembles finis et le principe de l'induction complète. Acta mathematica 32, 185-193.

Zermelo, E. 1909a. Über die Grundlagen der Arithmetik. Atti del IV Congresso internazionale dei matematici (Roma, 6-11 Aprile 1908) 2. Rome: Accademia dei Lincei, 8-11.

Zermelo, E. 1921. Thesen über das Unendliche in der Mathematik. Nachlaß. Published in: [van Dalen, Ebbinghaus 2000].

Zermelo, E. 1929. Über den Begriff der Definitheit in der Axiomatik. Fundamenta Mathematicae 14, 339-344.

Zermelo, E. 1929a. Neun Vorträge über die Grundlagen der Mathematik (Universität Warschau, 27. Mai - 8. Juni 1929). First and fourth of these abstracts published in: [Moore 1980].

Zermelo, E. 1930. Über Grenzzahlen und Mengenbereiche: Neue Untersuchungen über die Grundlagen der Mengenlehre. Fundamenta Mathematicae 16, 29-47.

Zermelo, E. 1930a. Über die logische Form der mathematischen Theorien. Annales de la société polonaise de mathématiques $\mathbf{9}, 187$.

Zermelo, E. 1931(?). Bericht an die Notgemeinschaft der Deutschen Wissenschaft über meine Forschungen betreffend die Grundlagen der Mathematik. Nachlaß. Published in: [Moore 1980].

Zermelo, E. 1931a. Letters to Gödel: September, 21 (published in [Dawson 1985]) and October, 29 (published in: [GrattanGuinness 1979]).

Zermelo, E. 1932. Über Stufen der Quantifikation und die Logik des Unendlichen. Jahresbericht der Deutschen Mathematiker-Vereinigung 41, 85-92.

Zermelo, E. 1932a. Über mathematische Systeme und die Logik des Unendlichen. Forschungen und Fortschritte 8, 6-7.

Zermelo, E. 1935. Grundlagen einer allgemeinen Theorie der mathematischen Satzsysteme (Erste Mitteilung). Fundamenta Mathematicae 25, 135-146.

Zermelo, E. 1937. Der Relativismus in der Mengenlehre und der sogenannte Skolem'sche Satz. Nachlaß. Published in: [van Dalen, Ebbinghaus 2000]. 


\section{Wykorzystywane notatki własne}

Druga Wyprawa Przeciw Skolemitom. O znaczeniu twierdzeń metalogicznych dla teorii jezyka. Niepublikowany tekst wykładu wygłoszonego 15 kwietnia 2002 roku w Instytucie Językoznawstwa w Poznaniu.

Systemy kanoniczne Romana Suszki. Trzy (albo 4?) odczyty wygłoszone na Seminarium Opolskim, Instytut Matematyki i Informatyki Uniwersytetu Opolskiego, wiosna 2002 roku [wspólnie z prof. Jackiem Hawrankiem].

Po co metalogika lingwistom? Odczyt wygłoszony podczas uroczystej sesji Komitetu Nauk Językoznawczych PAN, Warszawa, kwiecień 2002.

Jak żyć z paradoksem Skolema? Odczyt wygłoszony podczas VIII Konferencji Zastosowania Logiki w Filozofii i Podstawach Matematyki, Karpacz, maj 2002.

O paradoksie Skolema. Odczyt wygłoszony podczas Warsztatów Logiczno-Filozoficznych, Zawoja, wrzesień 2002.

Resnik i Skolemici. Odczyt wygłoszony na Seminarium Opolskim, Instytut Matematyki i Informatyki Uniwersytetu Opolskiego, jesień 2002 roku.

Three Little Dots. Logicians' Nightmares. Tekst niepublikowany, Konstanz, wiosna 2003 roku.

O tworzeniu się pojęć metalogicznych. Kategoryczność, zwartość, petność i zupetność. Tekst niepublikowany, Konstanz, wiosna 2003 roku.

O tworzeniu (się?) pojęć metalogicznych. Odczyt wygłoszony podczas XLIX Konferencji Historii Logiki, Kraków, październik 2003.

Twierdzenie o niewspótmożliwości. Odczyt wygłoszony na Seminarium Opolskim, Instytut Matematyki i Informatyki Uniwersytetu Opolskiego, listopad 2003.

Jak tworzq sie pojecia metalogiczne? Odczyt wygłoszony podczas konferencji Von Neumann's Birth Centenary Conference. Computational Power for Social Research, Zakopane, grudzień 2003.

Mrzonka metalogiczna - Gabelbarkeitssatz Carnapa. Odczyt wygłoszony na seminarium Zakładu Logiki Matematycznej UAM w Poznaniu, grudzień 2003.

Ku świadomej impotencji. Samoograniczenia metalogiczne. Odczyt wygłoszony podczas VIII Konferencji Zastosowania Algebry, Zakopane, marzec 2004.

Zermelo: antyskolemizm dobrze ufundowany. Odczyt wygłoszony podczas IX Konferencji Zastosowania Logiki w Filozofii i Podstawach Matematyki, Karpacz, maj 2004.

Zermelo: poczatki logiki infinitarnej. Odczyt wygłoszony na seminarium Zakładu Logiki Stosowanej UAM w Poznaniu, październik 2004.

Zermelo i Skolemici. Odczyt wygłoszony podczas L Konferencji Historii Logiki, Kraków, październik 2004.

Wielokropek. Odczyt wygłoszony podczas X Konferencji Zastosowania Logiki w Filozofii i Podstawach Matematyki, Szklarska Poręba, maj 2005. 